Linköping Studies in Science and Technology

Thesis No. 1739

\title{
Effect of Dwell-times on Crack Propagation in Superalloys
}

\author{
Jonas Saarimäki
}


Front page image: The general crack growth behaviour of Inconel 718 run at $550{ }^{\circ} \mathrm{C}$, subjected to a $2160 \mathrm{~s}$ dwell-time, with a $15 \%$ overload at the beginning of the dwell-time.

During the course of research underlying this thesis, Jonas Saarimäki was enrolled in Agora Materiae, a multidiciplinary doctoral program at Linköping University, Sweden.

(C) Jonas Saarimäki

ISBN 978-91-7685-871-4

ISSN 0280-7971

Printed by LiU-Tryck 2015 


\section{Abstract}

Gas turbines are widely used in industry for power generation and as a power source at "hard to reach" locations where other possibilities for electrical supply are insufficient. There is a strong need for greener energy, considering the effect that pollution has had on global warming, and we need to come up with ways of producing cleaner electricity. A way to achieve this is by increasing the combustion temperature in gas turbines. This increases the demand on the high temperature performance of the materials used e.g. superalloys in the turbine. These high combustion temperatures can lead to detrimental degradation of critical components. These components are commonly subjected to cyclic loading of different types e.g. combined with dwell-times and overloads at elevated temperatures, which influence the crack growth. Dwell-times have shown to accelerate crack growth and change the cracking behaviour in both Inconel 718 and Haynes 282. Overloads at the beginning of the dwell-time cycle have shown to retard the dwell time effect on crack growth in Inconel 718. To understand these effects more microstructural investigations are needed.

The work presented in this licentiate thesis was conducted under the umbrella of the research program Turbo Power; "High temperature fatigue crack propagation in nickel-based superalloys", concentrating on fatigue crack growth mechanisms in superalloys during dwell-times, which have shown to have a devastating effect on the crack propagation behaviour. Mechanical testing was performed under operation-like conditions in order to achieve representative microstructures and material data for the subsequent microstructural work. The microstructures were microscopically investigated in a scanning electron microscope (SEM) using electron channeling contrast imaging (ECCI) as well as using light optical microscopy.

The outcome of this work has shown that there is a significant increase in crack growth rate when dwell-times are introduced at the maximum load $(0 \%$ overload) in the fatigue cycle. With the introduction of a dwell-time there is also a shift from transgranular to intergranular crack growth for both Inconel 718 
and Haynes 282. When an overload is applied prior to the dwell-time, the crack growth rate decreases with increasing overload levels in Inconel 718. At high temperature crack growth in Inconel 718 took place as intergranular crack growth along grain boundaries due to oxidation and the creation of nanometric voids. Another observed growth mechanism was crack advance along $\delta$ phase boundaries with subsequent severe oxidation of the $\delta$ phase.

This thesis comprises two parts. The first giving an introduction to the field of superalloys and the acting microstructural mechanisms that influence fatigue during dwell times. The second part consists of two appended papers, which report the work completed so far in the project. 


\section{Populärvetenskaplig sammanfattning}

Gasturbiner används över hela världen för el- och kraftproduktion, i allt från pumpar och skepp till svåråtkomliga områden i berg och djungel där kraftnätet kan vara ostabilt och nästintill icke existerande. Idag är efterfrågan av grön el större än någonsin, med tanke på de utsläpp som bidrar till växthuseffekten. Det här betyder att vi behöver komma på ett sätt att producera renare el. Ett sätt, är att öka förbränningstemperaturen i våra gasturbiner. Att öka förbränningstemperaturen ökar kraven på de material som används, mestadels superlegeringar. Den här temperaturökningen kan leda till skadlig nedbrytning av kritiska komponenter. Dessa komponenter är vanligtvis utsatta för cykliska laster av olika typer t.ex. i kombination med hålltider och överlaster som påverkar spricktillväxten. Hålltider har visats att både öka spricktillväxthastigheten och ändra sprickbeteendet i både Inconel 718 och Haynes 282. Överlasten i början av hålltidscykeln visade sig att retardera hålltidseffekten på spricktillväxten i Inconel 718. För att öka förståelsen för hur de här effekterna påverkar mikrostrukturen krävs det mer forskning inom området.

Arbetet presenterat i den här licentiatavhandlingen har gjorts i projektet Turbokraft; "Högtemperaturutmatning och sprickpropagering i nickel-bas superlegeringar", inriktat på spricktillväxtmekanismer vid hålltider. Hålltider har visat sig ha en förödande effekt på sprickpropageringsbeteendet. Mekanisk provning har utförts under operationsliknande förhållanden (med avseende på cykeltyp och temperatur för att efterlikna delar av verkliga lastfall) för att i största mån återskapa verkliga förhållanden och åstadkomma representativa mikrostrukturer och data. Mikrosturkturerna undersöktes både i ett svep elektron mikroskop (SEM) med hjälp av elektron kannelering kontrast avbildning (ECCI) samt med ljusoptisk mikroskopering. Sprickpropagering i Inconel 718 vid hög temperatur

Resultaten hittills visar att effekten av hålltider vid maxlasten ( 0 \% överlast) markant ökar spricktillväxthastigheten under utmattningscykeln. När hålltiden introduceras byter även sprickpropagering modus från transkristallin till inter- 
kristallin spricktillväxt för både Inconel 718 och Haynes 282. När en överlast introducerats i början av hålltidscykeln avtog sprickpropageringshastigheten i takt med att överlasten ökades. Sprickpropagering i Inconel 718 vid hög temperatur skedde interkristallint längs korngränserna p.g.a. oxidation och bildning av nanometriska kaviteter (krypskada). En annan mekanism som observerades var sprickpropageringen längs $\delta$-fasgränser var efter $\delta$-fasen allvarligt oxiderade.

Den här licentiatavhandlingen består av två delar. Den första ger läsaren en introduktion till fältet superlegeringar och de mekanismer som styr hålltidsutmattning. Den andra delen består av två bifogade artiklar, som sammanfattar den hittills avklarade delen av projektet. 


\section{Acknowledgements}

As always, it is truly hard to write the acknowledgements for any thesis or article, as it is fraught with danger. If you mention to few some might feel left out and vexed that they were not included. Mention to many and you will come of like one of the artists from the MTV music awards thanking every famous person for inspiration, non-existent assistance, and so forth. So here we go.

Firstly I would like say that this research has been carried out at the Division of Engineering Materials, Department of Management and Engineering, Linköping University, Sweden. The Project was financially funded by the Swedish Energy Agency, GKN Aerospace Engine Systems, Siemens Industrial Turbomachinery $\mathrm{AB}$, and the Royal Institute of Technology through the Swedish research program Turbo Power, the support of which is gratefully acknowledged. During the course of research underlying this thesis, I was enrolled in Agora Materiae, a multidiciplinary doctoral program at Linköping University, Sweden. Through witch I have made some new friends, for with I am truly grateful. So thank you Per-Olof Holtz for running Agora Materiae.

During the course of this work I have received help from many, without I would probably not have gotten too far. Therefore I would like to express my sincere gratitude to:

To my supervisor Johan Moverare. Without I would have never gotten the chance to continue my academic career in such a fun and interesting field such as fatigue in superalloys at elevated temperatures.

To my co supervisors Kjell Simonsson, who can probably explain the most complicated solid mechanics problems in such way that even I can get an understanding of them. Magnus Hörnqvist Colliander, who is sharp like a Zwilling knife, fun to talk to and seems to know everything in beforehand. Robert Eriksson, it might be like everybody says, he knows everything, and is great with programming as well, to the good times in the lab.

I would also like to thank the men and women working at the Division of Engineering Materials, for creating a fun and stimulating workplace and all our 
technicians for without the working temperature in the lab would stay at a constant temperature of $0 \mathrm{~K}$.

A special thanks to Christopher Tholander who has made some of my mindboggling computer and programming problems seem ridiculously simple $\odot$.

To the people outside work who makes my life in to the utopia I am always claiming it to be

Vlärdens bästa mamma.

My aunt and Uncle Mariaana and Charlie.

Finally to Jennifer and Plutten (Jasmine) for giving me a wonderful family.

To Plutten, I wrote this licentiate thesis for you, but when I began I had not realised that girls grow quicker than chapters. I think we will be able to use this as a very effective bedtime story for quite some time. But one day you will be old enough to start thinking about reading this. You can then take it down from some upper shelf or box in the basement, dust it off, and tell me what you think of it. I will probably be too deaf to hear, and too old to understand, a word you say, but I will still be your mount papa.
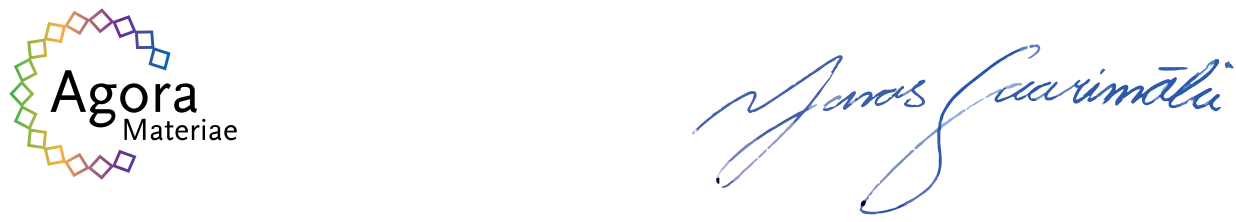

Jonas Saarimäi

Linköping, November 2015 
1 Introduction $\quad 1$

1.1 Background .......................... 1

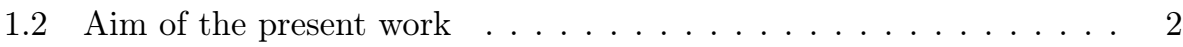

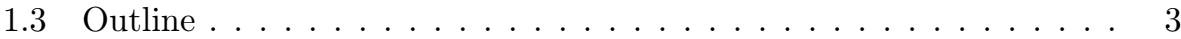

2 Gas turbines 5

2.1 General description . . . . . . . . . . . . . . . . . 6

2.2 The step by step explanation . . . . . . . . . . . . . 6

2.2 .1 Function ................... 8

3 Superalloys 11

3.1 Alloying elements . . . . . . . . . . . . . . . . . 13

3.2 Phases in Ni-base superalloys . . . . . . . . . . . . . 17

4 Experimental procedures $\quad \mathbf{1 9}$

4.1 Inconel 718, KB test specimen experimental procedure . . . . . . . . 19

4.1 Specimens . . . . . . . . . . . . . . . 20

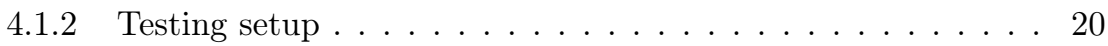

4.1.3 Crack growth measurements . . . . . . . . . . . . 21

4.2 Haynes 282, CT test specimen experimental procedure . . . . . . . 22

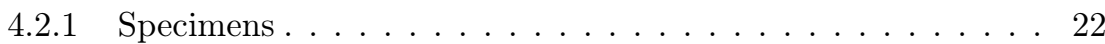

4.2.2 Room temperature crack propagation test setup . . . . . . . . 23

4.2.3 High temperature crack propagation test setup . . . . . . . . 24

4.3 Microscopy and image analysis . . . . . . . . . . . . . 25

4.3.1 Electron channelling contrast imaging . . . . . . . . . . 25

4.4 Potential drop . . . . . . . . . . . . . . . . . . . . . . . 29 
5 Crack propagation 31

5.1 Dynamic embrittlement . . . . . . . . . . . . . . 32

5.2 Stress accelerated grain boundary oxidation . . . . . . . . . . . . . 34

5.3 Brittle/cleavage striations . . . . . . . . . . . . . . . . 34

5.4 Crack tip blunting . . . . . . . . . . . . . . . . . . . . . . . . . . . . . . . . . 35

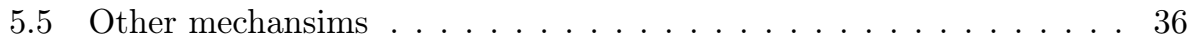

$\begin{array}{llr}6 & \text { Summary } & 37\end{array}$

$\begin{array}{ll}\text { Bibliography } & 39\end{array}$

7 Results and included papers $\quad 47$

7.1 List of publications . . . . . . . . . . . . . . . . . . . . . . . . . . 48

7.2 Summary of included papers . . . . . . . . . . . . . . . 49

$\begin{array}{ll}\text { Paper I } & 51\end{array}$

$\begin{array}{ll}\text { Paper II } & 61\end{array}$ 
CHAPTER 1

\section{Introduction}

\subsection{Background}

Gas turbines are widely used in industry for power generation and as a power source at "hard to reach" locations where other possibilities for electrical supply are insufficient [1]. In the logistics sector turbines are frequently used in aviation industry. The effect of global warming has increased the demand and need for greener energy. Therefore, we need more efficient gas turbines. This in turn raises the demands on higher performance materials used in gas turbines [2], one way to increase the efficiency of a turbine is to increase the operating temperature e.g. the combustion temperature [3]. Different types of turbines have been developed through time since the first steam engine developed by Hero, until 1920 when the "first" gas turbine was developed, and about twenty years later the first air-borne turbine became available. The key to successfully develop better performing turbines has been due to the improvements in the field of superalloys. Superalloys are not only used in turbine discs and blades but in many applications such as burner nozzles, power plants, aqueous, space, petrochemical applications and many others. Superalloys are a group of nickel-, iron-nickel and cobalt-base materials that combine mechanical properties and corrosion resistance that can be used successfully up to temperatures as high as $1000{ }^{\circ} \mathrm{C}[4]$. At these high temperatures most other relevant material groups e.g. steel demonstrates extremely poor properties.

Even though superalloys have shown a positive combination of mechanical properties and corrosion resistance, they are used in some of the worlds most aggressive working conditions. These harsh conditions are detrimental to the alloy in the form of e.g. corrosion, oxidation, erosion, thermal-mechanical fatigue, low cycle fatigue, high cycle fatigue, creep, microstructural degradation which all can lead to catastrophic failure. When components such as turbine discs are used 
they are subjected to high temperatures and significant centrifugal forces generated when running at speeds up to $9000 \mathrm{rpm}$. The life of a component is usually correlated to the amount of stop and start cycles or takeoffs and landings, since turbines are mostly run at a constant load level e.g. a transatlantic flight. This means that the fatigue life [5] is of out most importance when designing turbine components. Today it is well known that fatigue cracks are commonly initiated at surfaces [6] and that the fatigue crack growth rate is highly cycle type dependent. A well suited cycle used for simulating a run cycle from start to stop is a dwell-time cycle which has been shown in [7] to increase crack growth rate. For crack growth rates to be fully or at least more understood, microstructure and cycle dependence is of outmost interest and need to be studied to enable an increase in fatigue life.

\subsection{Aim of the present work}

The work carried out in this licentiate thesis is made within the Turbo Power project; High temperature fatigue crack propagation in nickel-based superalloys, concentrating on fatigue crack growth mechanisms in superalloys during dwelltimes, which have shown to have a devastating effect on the crack propagation behaviour. The project involves a strong collaboration between academia and industry e.g. Linköping University, Siemens Industrial Turbomachinery AB in Finspång, Sweden, and GKN Aerospace Engine Systems in Trollhättan, Sweden. This research has been funded by the Swedish Energy Agency, Siemens Industrial Turbomachinery AB, GKN Aerospace Engine Systems, and the Royal Institute of Technology under the umbrella of the Swedish research project Turbo Power.

Siemens Industrial Turbomachinery AB and GKN Aerospace Engine Systems are the two main collaboration partners in this project, therefore, the testing methods have been directed towards the operating cycles of turbines e.g. dwell-times, simulating a part of a transatlantic flight or part of a "normal" run cycle for a land based gas turbine. The materials researched in this thesis are Inconel 718 (bar) and HAynes 282 (in the form of a forged ring). Inconel 718 is frequently used as a disc material in land-based gas turbines and Haynes 282, a quite newly developed Ni-base superalloy, is a candidate for several high-temperature applications in both aero and land-based gas turbine engines. The design of a land-based gas turbine and a aero engine are quite similar which means that the presented research in this thesis could be of use to both industries. The main goals have been to find a way to describe crack growth and determine which mechanisms are present. Determine if the mechanism/mechanisms is a leading one, if so, in what way does it effect the crack growth i.e., retarding or accelerating. 


\subsection{Outline}

The first part of this thesis gives the reader an introduction to the field of nickelbased superalloys, what makes them super and the most common mechanisms used to explain fatigue crack propagation, emphasising the effects concerning dwelltimes and over-loads. The second part consists of 2 appended papers, which report the work completed so far in the project. 


\section{CHAPTER 2}

\section{Gas turbines}

Gas turbines are used for a large variety of applications. Turbines are used in both civil as well as military aircraft and helicopters. When looking at electrical power generation gas turbines of all shapes and sizes are used, micro-turbines with a power output of $20 \mathrm{~kW}-350 \mathrm{~kW}$ up to the largest Frame-type with a power output of $3 \mathrm{MW}-480 \mathrm{MW}$ and a thermal efficiency of $15-46 \%$ when used in a single cycle configuration [8]. Gas turbines prefer a constant rather than a fluctuating load. This makes gas turbines superior for applications like power plants, transcontinental jet aircraft, helicopters and it could be one of the main reasons why we do not see them in nearly any of our cars, buses, trains and ships. Gas turbines like the SGT-500, 600, 700 and 750 are biaxial and can therefore be used to drive machinery such as generators, cruise ships and destroyers. They are also used to drive oil and gas pipeline pumps all over the world in environments where the weather conditions vary from the arctic colds in Siberia to the hot climates of Thailand. When used to drive other machinery the turbines are connected to two separate shafts, one for the compressor and the other for mechanical work. The main disadvantage for gas turbine engines compared to reciprocating/equivalent diesel engines of the same size is the prize. Because gas turbines spin at high speeds and have very high operating temperatures they are hard to design and manufacture. The present work is focused on the materials used in industrial power generation. 


\subsection{General description}

Simple-cycle gas turbines can, according to [1], be classified into five general groups:

- Frame type heavy-duty gas turbines. Frame units are large power generating units that range from $3 \mathrm{MW}$ to $480 \mathrm{MW}$ in a simple cycle configuration, with efficiencies ranging from $30-46 \%$.

- Aircraft-derivative gas turbines aero-derivative. As the name indicates, these are power generating units, which originated in the aerospace industry as the prime mover of aircraft. These units have been adapted to the electrical generation industry by removing the bypass fans, and adding a power turbine at their exhaust. These units range in power from $2.5 \mathrm{MW}$ to about $50 \mathrm{MW}$. The efficiencies of these units can range from $35-45 \%$.

- Industrial type-gas turbines (IGT). These vary in range from about $5 \mathrm{MW}-40 \mathrm{MW}$. This type of turbine is used extensively in many petrochemical plants to drive compressors. The efficiencies of these units is between $15-35 \%$.

- Small gas turbines. These gas turbines are in the range from about 0.5 MW - 2.5 MW. They often have centrifugal compressors and radial inflow turbines. Efficiencies vary from $15-25 \%$.

- Micro-turbines. These turbines are in the range from $20 \mathrm{~kW}-350 \mathrm{~kW}$.

All gas turbines work according to the same principle being the Joule/Brayton cycle as seen in Fig. 2.1. Fig. 2.1 (b) and (c) shows that the ideal Joule/Brayton cycle has one stage of isentropic compression between points a and $b$ and an isentropic expansion stage between points c and d. Energy (q1) a.k.a. fuel is added at constant pressure between points $b$ and $c$, resulting in an increase in temperature and volume expansion. Increasing the working temperature will lead to an increased efficiency [2] according to

$$
\eta=1-\frac{T_{d i s}}{T_{c}}=\left(\frac{p_{1}}{p_{2}}\right)^{(\kappa-1) / \kappa}
$$

which is used to calculate the thermal efficiency for the Joule/Brayton cycle, where $\eta$ is the thermal efficiency, $T_{c}$ is the combustion temperature and $T_{d i s}$ is the turbine outlet temperature, $\kappa$ is the adiabatic exponent and $p_{1}$ and $P_{2}$ are the pressures after and before compression respectively [9].

\subsection{The step by step explanation}

The process can also be explained in another way, such as, a gas is compressed and the compressed gas spins the turbine. The gas consists of compressed air and fuel, both liquid and gaseous fuels can be used. The most common liquid fuels are oils, 
a)

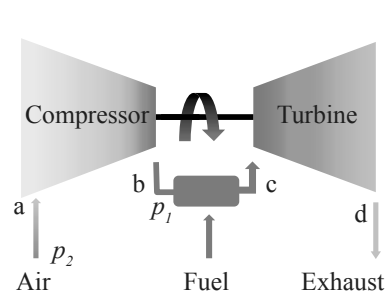

b)

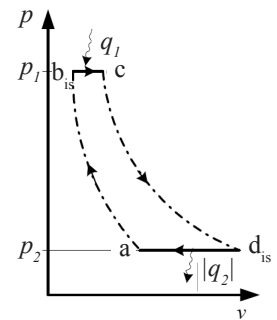

c)

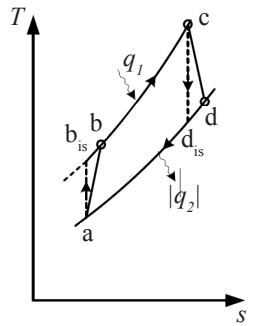

Figure 2.1. (a) Schematic picture of an open circuit gas turbine system. (b) and (c) shows where points a, b, c, and d correspond to the different steps of the Joule Brayton cycle, points denoted is are isotropic values and $q_{1}$ and $q_{2}$ are energy input and output respectively.

ethanol and methanol and the most common gaseous fuels are natural gas, propane and butane [1]. The fuel is mixed with the compressed air and then combusted. The heat from the combustion process expands the air, which in turn drives the turbine. It is of out most importance that only gases flow through the turbine otherwise the turbine blades will deteriorate rapidly due to drop erosion. There are different gas turbine designs based on different theories of what works best, for example annular combustion chambers and can-annular combustion chambers. Some say that a gas turbine will only work properly if it has an odd number of burners and will always fail if it has an even number of burners [10]. The annular combustor is generally placed inside and the can-annular outside the envelope of compressor and turbine. The annular combustor is a single combustor with multiple fuel nozzles and an inner wall that act as a heat shield to protect the rotor. The can-annular combustors can also be divided into two groups, one with a straight flow-through the combustor and the other with a reverse flow combustor. The reverse flow combustor that is used in heavy industrial gas turbines facilitates the use of a regenerator [11], which improves overall thermal efficiency.

In Fig. 2.3 a cross section of the Siemens industrial gas turbine SGT-750 can be seen. The SGT-750 is a large turbine that can be used for mechanical drive and electrical power generation or in a combined power and heat generation cycle. A combined power and heat generation cycle is shown in Fig. 2.2. When turbines are are used for combined power and heat generation a total electrical efficiency of $>60 \%$ can be achieved [12].

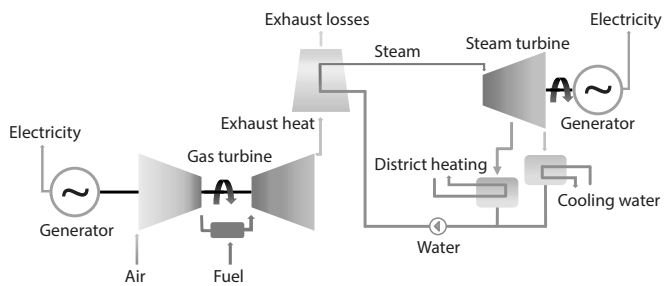

Figure 2.2. The combined cycle process showing the incorporation of a steam turbine for additional electrical production as well as district heating. 


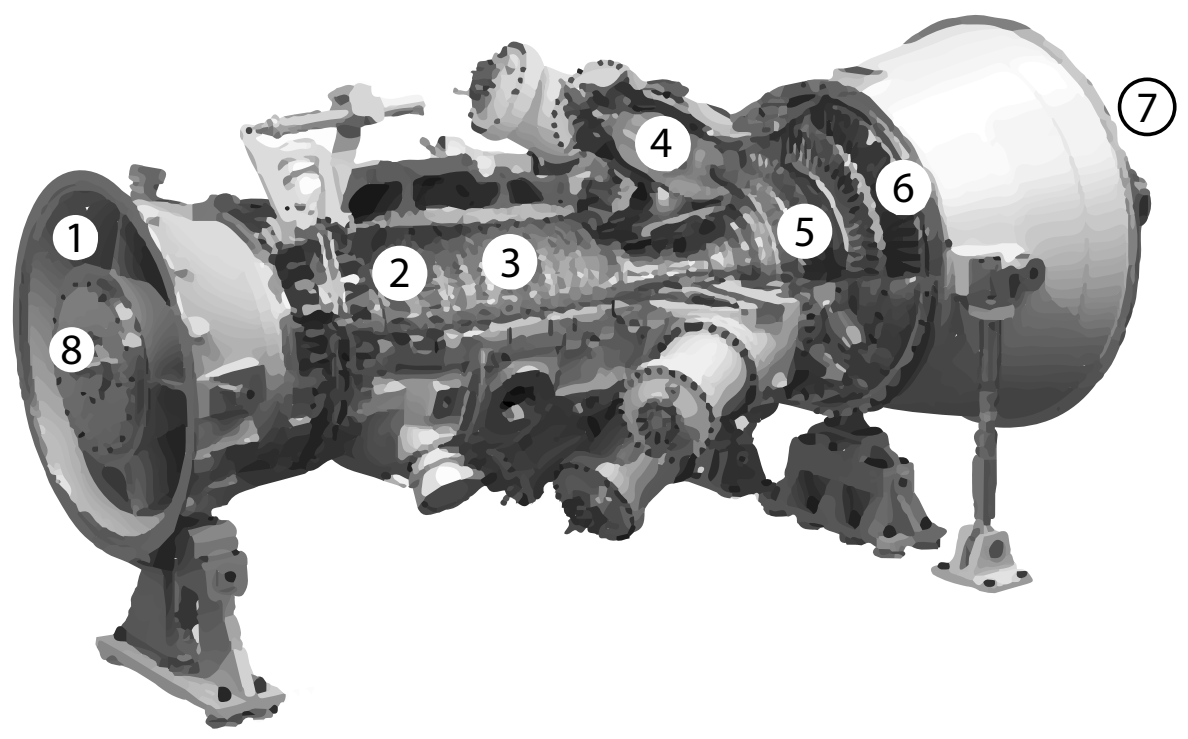

Figure 2.3. Siemens Industrial Gas Turbine SGT-750 (Courtesy of Siemens Industrial Turbomachinery AB.

\subsubsection{Function}

The following explanation and data used are specific to the SGT-750 and will vary between machines and manufacturers.

1. Air is sucked in at approximately $130 \mathrm{~m}^{3}$ per second [13] through the air intake that acts as a huge funnel in to the compressor.

2. The air flows through variable guide vanes which are used to optimise the performance of the air flow. It is optimised by directing the intake air depending on the intake air quality taking into account weather conditions, such as temperature range and particle size of air born contaminants to optimise the flow through the compressor.

3. The air is then compressed in the 13-stage axial flow compressor with a $23.8: 1$ pressure ratio [13]. Between every compression stage there is a stage of vanes that are stationary which yet again redirects the flow of the compressed air to optimise efficiency.

4. The compressed air is mixed with fuel in the can-annular combustors with DLE (dry low emission) burners. The SGT-750 runs on natural gas eventhou there are many different types of fuels available such as propane, kerosene and jet fuel as previously mentioned. Natural gas is used because it is the most "ECO" friendly alternative when taking pollution in to account. The fuel 
mixture is combusted at a temperature of more than $+1400{ }^{\circ} \mathrm{C}$ and expands the air. Combustor design is divided in two distinct configurations, annular and can-annular. Combustors in heavy industrial gas turbines usually have long combustion chambers which makes them more suitable for burning lower quality fuels that are cheaper and more freely available [10].

5. The exhaust temperature begins to decrease and goes through the first hot stage blades of the turbine. The first hot stage blades are subjected to very high temperatures and pressure. To protect them they are coated with a ceramic thermal barrier coating (TBC).

6. The temperature keeps decreasing and goes through the last stages of the turbine. The turbine rotates at speeds above $6000 \mathrm{rpm} \mathrm{[13]} \mathrm{which} \mathrm{results}$ in strong centrifugal ${ }^{1}$ forces. With a higher operating temperature a higher efficiency can be achieved. Because of the large centrifugal forces and high temperatures all parts must be made of the best possible materials, typically Ni-base superalloys.

7. The remaining excess heat from the exhaust can be around $500{ }^{\circ} \mathrm{C}[13]$ and depending on the user needs it can be used in combined cycle processes to produce steam for steam turbines and/or heat water in regenerative heatexchangers to supply warm water for district heating. By combining a gas turbine with a steam turbine and district heating the overall efficiency can be increased to over $90 \%$ [13]. A combined power and heat generation cycle is shown in figure 2.2

8. To start a gas turbine an electrical starter motor is connected to the shaft. Which in turn rotates the rotor until a high enough speed has been achieved to make it self-sustained. When the turbine is creating enough power to drive the compressor the electrical starter engine can be disconnected. Some turbines use diesel engines as starter motors and in the early days of gas turbine development they also used to blow pressurised air into the air intake to get it rotating.

\footnotetext{
${ }^{1}$ Centripetal forces for you physicists out there $\odot$.
} 


\section{CHAPTER 3}

\section{Superalloys}

Superalloys have been specifically designed to withstand service temperatures exceeding $540{ }^{\circ} \mathrm{C}$ [14] up to temperatures as high as $1000{ }^{\circ} \mathrm{C}$ [4]. These alloys can be either iron-, cobalt- or nickel-based. The later having gained the most interest from industries such as the gas turbine industry for high temperature components due to their superior mechanical and corrosion resistant properties at high temperatures. As seen in Fig. 3.1 the mechanical strength of Ni-based superalloys are far beyond that of the other alloy groups.

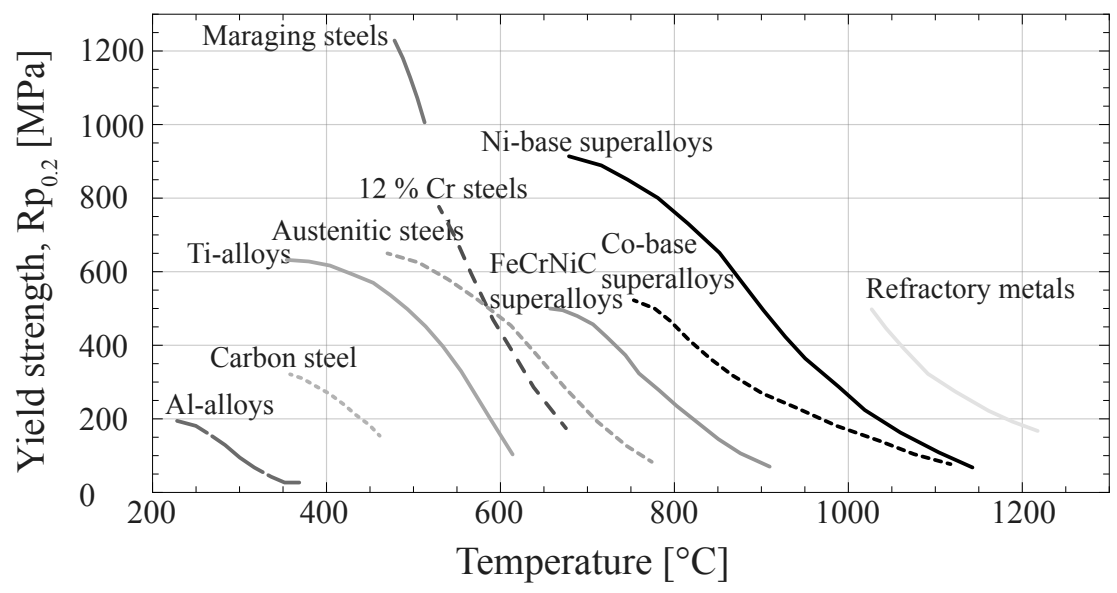

Figure 3.1. Maximum service temperature for different groups of creep-resistant alloys, adapted from [15], where denoted 0.2 is an offset of the yield strength.

At temperatures above $\sim 540{ }^{\circ} \mathrm{C}$, ordinary steels and titanium alloys loose 
their mechanical properties and become inferior in comparison to the nickel based ones (steels are also more prone to corrosion at these elevated temperatures). If alloys are subjected to service temperatures as high as $1200{ }^{\circ} \mathrm{C}$ to $1370{ }^{\circ} \mathrm{C}$, the only alloy group that can maintain its mechanical properties are the nickel-base superalloys. As seen in Fig. 3.1, the refractory metals such as Tungsten could be considered but they lack the desired characteristics i.e., ductility of superalloys [14]. Cobalt-base superalloys can be used instead of nickel-base ones but are in many cases not as strong and corrosion resistant as the nickel-base ones. At lower service temperatures (turbine discs), iron-nickel-base superalloys such as Inconel 718 are are used to a larger extent than the cobalt- or nickel-base superalloys and are in general also less expensive.

The strength of superalloys can of course be related to chemistry as well as to melting/casting procedures, and mechanical work processes, but especially to heat treatments following forming, forging or casting. Superalloys are made of several elements from minuscule to major amounts. The most common ones being nickel, chromium, molybdenum, aluminium and carbon.

Most wrought superalloys have quite high Cr-levels to provide corrosion resistance and are suited for machining and welding. The Cr-content in cast alloys have been reduced over time and been replaced by other strengthening elements [14] and are complicated to machine by conventional methods such as turning and milling. The decrease in Cr-content in Ni-base superalloys has been compensated with a higher Al-content resulting in similar oxidation resistance, but a decreased resistance to other types of detrimental corrosive attacks.

In general, superalloys have great oxidation resistance, but usually poorer corrosion resistance. In the hotter parts of aircraft turbines $\left(>760{ }^{\circ} \mathrm{C}\right)$ and for components subjected to high temperatures $\left(650{ }^{\circ} \mathrm{C}\right)$ for long periods of time as in land based gas turbines, the superalloys need a thermal barrier coating (TBC). TBC's are used to protect superalloys from e.g. heat and harmful elements and therefore extend the total life of the components. The need for TBC's can also be seen in Fig. 3.2 where at $\sim 700{ }^{\circ} \mathrm{C}$ the yield strength of the alloys start to degrade rapidly.

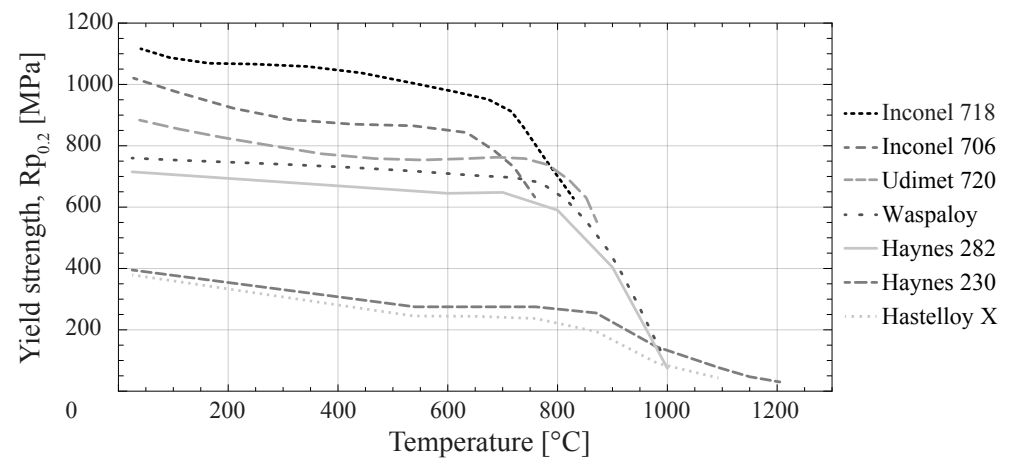

Figure 3.2. Yield strength of the wrought alloy compositions from Table 3.1 at different temperatures, adapted from [16-18], where denoted 0.2 is an offset of the yield strength. 


\subsection{Alloying elements}

As seen in Fig. 3.1, Ni-base superalloys are especially suitable for high temperature applications. They often contain multiple alloying elements which make them very advanced, nonetheless they are vastly used and of great interest to industry and their different properties e.g. mechanical and corrosive are often well documented [14, 19-21]. There are three general classes of Ni-base superalloys: wrought, cast, and powder metallurgy (PM) alloys.

Wrought alloys are suited for mechanical work such as turning, milling and welding. The composition of some common wrought superalloys are given in Table 3.1. They are often strengthened through solid solution strengthening and/or through the formation of a second coherent phase namely $\gamma^{\prime}[22]$ in e.g. Haynes 282 or $\gamma^{\prime \prime}$ in e.g. Inconel 718. In many cases the $\gamma^{\prime}$ and $\gamma^{\prime \prime}$ are precipitated during heat treatments.

Table 3.1. Compositions (in weight \%) of some common wrought superalloys [23].

\begin{tabular}{lcccccccccccc}
\hline Alloy & $\mathrm{Ni}$ & $\mathrm{Cr}$ & $\mathrm{Co}$ & $\mathrm{Mo}$ & $\mathrm{W}$ & $\mathrm{Nb}$ & $\mathrm{Al}$ & $\mathrm{Ti}$ & $\mathrm{Fe}$ & $\mathrm{C}$ & $\mathrm{B}$ & $\mathrm{Zr}$ \\
\hline Hastelloy X & Bal. & 22.0 & 1.5 & 9.0 & 0.6 & - & 0.25 & - & 18.5 & 0.1 & - & - \\
Haynes 230 & Bal. & 22.0 & - & 2.0 & 14.0 & - & 0.3 & - & - & 0.10 & - & - \\
Haynes 282 & Bal. & 19.6 & 10.3 & 8.7 & 0.01 & 0.10 & 1.5 & 2.2 & 0.5 & 0.06 & 0.005 & - \\
Inconel 706 & Bal. & 16.0 & - & - & - & 2.9 & 0.2 & 1.8 & 40.0 & 0.03 & - & - \\
Inconel 718 & Bal. & 19.0 & - & 3.0 & - & 5.1 & 0.5 & 0.9 & 18.5 & 0.04 & - & - \\
Udimet 720 & Bal. & 17.9 & 14.7 & 3.0 & 1.25 & - & 2.5 & 5.0 & - & 0.035 & 0.033 & 0.03 \\
Waspaloy & Bal. & 19.5 & 13.5 & 4.3 & - & - & 1.3 & 3.0 & - & 0.08 & 0.006 & - \\
\hline
\end{tabular}

Looking at cast superalloys we see that there are three subdivisions: polycrystalline, directionally solidified (DS) and the most advanced of the three subdivisions namely the single crystal. The composition of some common cast superalloys are given in Table 3.2. In comparison to wrought superalloys cast superalloys are often more difficult to machine by turning and/or milling. Just as in the wrought superalloys the strengthening phases are $\gamma^{\prime}$ and $\gamma^{\prime \prime}$.

Table 3.2. Compositions (in weight \%) of some cast superalloys [24].

\begin{tabular}{lllllllllllllc}
\hline Alloy & $\mathrm{Ni}$ & $\mathrm{Cr}$ & $\mathrm{Co}$ & $\mathrm{Mo}$ & $\mathrm{W}$ & $\mathrm{Nb}$ & $\mathrm{Al}$ & $\mathrm{Ti}$ & $\mathrm{Fe}$ & $\mathrm{C}$ & $\mathrm{B}$ & $\mathrm{Zr}$ & Other \\
\hline Hastelloy X & 50 & 21 & 1 & 9 & 1 & - & - & - & 18 & 0.1 & - & - & - \\
Inconel 718 & 53 & 19 & - & 3 & - & 5 & 0.5 & 0.9 & 18 & 0.04 & - & - & $0.1 \mathrm{Cu}$ \\
Waspaloy & 57.3 & 19.5 & 13.5 & 4.2 & - & - & 1.2 & 3.0 & - & 0.07 & 0.005 & 0.09 & - \\
\hline
\end{tabular}

The biggest advantage when casting is that not only regular polycrystalline materials can be cast but directionally solidified and single crystal materials as well. The directionally solidified and single crystal materials can this way be engineered in such a way to improve creep properties by reducing the amount of grains and grainboundaries. This also means that the Young's modulus can be engineered through anisotropy making it possible to increase fatigue life.

Most elements commonly used in superalloys have different effects which are shown in Table 3.3 and 3.4. These elements improve the mechanical strength 
through solid solution strengthening and/or precipitation hardening. Precipitates can be in the form of carbides based on various elements. Chromium improves corrosion resistance and aluminium improves oxidation resistance but both also strengthen the matrix, although aluminium has a high affinity to create $\gamma^{\prime}$ phase. To harden the matrix heavy elements are used such as molybdenum, tungsten (wolfram), niobium and tantalum. The downside of using heavy elements is the increased density which is the opposite of what is optimal for aeronautical applications. Even though these elements have positive properties, when used excessively they can form topologically close-packed phases (TCP) such as the unwanted and brittle $\sigma$ and $\mu$ phase $[25,26]$. The principal elements that are used when forming $\gamma^{\prime}$ are aluminium and titanium, in some cases niobium and tantalum. Since tantalum can replace titanium in single crystal superalloys and is used to raise the solidus temperatures and the volume fraction of $\gamma^{\prime}$ can be increased to between 70 and $80 \%$ in single crystal alloys. For more in-depth information on the effect of alloying elements in superalloys, there are vast amounts of literature available [19-21]. 
Table 3.3. Effects of major alloying elements in nickel base superalloys [25].

\begin{tabular}{|c|c|c|c|c|c|}
\hline Element & $\begin{array}{l}\text { Matrix } \\
\text { Strengthening }\end{array}$ & $\begin{array}{l}\text { Increase in } \gamma^{\prime} \\
\text { volume fraction }\end{array}$ & $\begin{array}{l}\text { Grain } \\
\text { boundaries }\end{array}$ & Other effects & \pm \\
\hline $\mathrm{Cr}$ & Moderate & Moderate & $\begin{array}{l}\mathrm{M}_{23} \mathrm{C}_{6} \\
\mathrm{M}_{7} \mathrm{C}_{3}\end{array}$ & $\begin{array}{l}\text { Corrosion resistance } \\
\text { TCP phases }\end{array}$ & $\begin{array}{l}+ \\
+ \\
\end{array}$ \\
\hline Mo & High & Moderate & M6C \& MC & Increases density & \\
\hline $\mathrm{W}$ & High & Moderate & & TCP phases & - \\
\hline $\mathrm{Ta}$ & High & Large & & & \\
\hline $\mathrm{Nb}$ & High & Large & $\mathrm{NbC}$ & $\begin{array}{l}\text { Promotes } \gamma \text { phase } \\
\text { Promotes } \delta \text { phase }\end{array}$ & $\begin{array}{l}+ \\
+\end{array}$ \\
\hline $\mathrm{Ti}$ & Moderate & Very large & $\mathrm{TiC}$ & & \\
\hline $\mathrm{Al}$ & Moderate & Very large & & Oxidation resistance $\nearrow$ & + \\
\hline $\mathrm{Fe}$ & & $\gamma^{\prime} \rightarrow \beta, \eta, \gamma^{\prime \prime}, \delta$ & & $\begin{array}{l}\text { Oxidation resistance } \\
\text { TCP phases } \sigma, \text { Laves }\end{array}$ & \\
\hline Co & Slight & $\begin{array}{l}\text { Moderate in } \\
\text { some alloys }\end{array}$ & Carbides & Solidus temperature $\uparrow$ & + \\
\hline $\operatorname{Re}$ & Moderate & & & $\begin{array}{l}\text { Retards coarsening } \\
\text { Increases misfit }\end{array}$ & $\begin{array}{l}+ \\
+ \\
+\end{array}$ \\
\hline $\mathrm{C}$ & Moderate & & & & \\
\hline $\mathrm{B}, \mathrm{Zr}$ & Moderate & & & $\begin{array}{l}\text { Inhibit carbide coarsening } \\
\text { Improves grain boundary strength } \\
\text { Improves creep strength and ductility }\end{array}$ & $\begin{array}{l}+ \\
+ \\
+ \\
+\end{array}$ \\
\hline
\end{tabular}


Table 3.4. Effects of major alloying elements in nickel base superalloys [25].

\begin{tabular}{|c|c|c|c|}
\hline Effect * & Fe-base & Co-base & Ni-base \\
\hline Solid-solution strengtheners & $\mathrm{Cr}, \mathrm{Mo}$ & $\begin{array}{c}\mathrm{Nb}, \mathrm{Cr}, \mathrm{Mo}, \mathrm{Ni} \\
\mathrm{W}, \mathrm{Ta}\end{array}$ & $\begin{array}{c}\mathrm{Co}, \mathrm{Cr}, \mathrm{Fe}, \mathrm{Mo} \\
\text { W, Ta, Re }\end{array}$ \\
\hline FCC matrix stabilizers & $\mathrm{C}, \mathrm{W}, \mathrm{Ni}$ & $\mathrm{Ni}$ & - \\
\hline \multicolumn{4}{|l|}{ Carbide formers } \\
\hline $\mathrm{MC}$ & $\mathrm{Ti}$ & $\mathrm{Ti}$ & $\begin{array}{l}\text { W, Ta, Ti, Mo, } \\
\text { Nb, Hf }\end{array}$ \\
\hline $\mathrm{M}_{7} \mathrm{C}_{3}$ & - & $\mathrm{Cr}$ & $\mathrm{Cr}$ \\
\hline $\mathrm{M}_{23} \mathrm{C}_{3}$ & $\mathrm{Cr}$ & $\mathrm{Cr}$ & Cr, Mo, W \\
\hline $\mathrm{M}_{6} \mathrm{C}$ & Mo & Mo, W & Mo, W, Nb \\
\hline Carbonnitrides :M(CN) & $\mathrm{C}, \mathrm{N}$ & $\mathrm{C}, \mathrm{N}$ & $\mathrm{C}, \mathrm{N}$ \\
\hline $\begin{array}{l}\text { Promotes general precipitation of } \\
\text { carbides }\end{array}$ & $\mathrm{P}$ & - & - \\
\hline Forms $\gamma^{\prime} \mathrm{Ni}_{3}(\mathrm{Al}, \mathrm{Ti})$ & $\mathrm{Al}, \mathrm{Ni}, \mathrm{Ti}$ & - & $\mathrm{Al}, \mathrm{Ti}$ \\
\hline $\begin{array}{l}\text { Retards formation of hexagonal } \\
\eta\left(\mathrm{Ni}_{3} \mathrm{Ti}\right)\end{array}$ & $\mathrm{Al}, \mathrm{Zr}$ & - & - \\
\hline Raises solvus temperature of $\gamma^{\prime}$ & - & - & $\mathrm{Co}$ \\
\hline $\begin{array}{l}\text { Hardening precipitates and/or } \\
\text { intermetallics }\end{array}$ & $\mathrm{Al}, \mathrm{Ti}, \mathrm{Nb}$ & $\begin{array}{c}\mathrm{Al}, \mathrm{Mo}, \mathrm{Ti}^{* *}, \mathrm{~W} \\
\mathrm{Ta} \\
\end{array}$ & $\mathrm{Al}, \mathrm{Ti}, \mathrm{Nb}$ \\
\hline Oxidation resistance & $\mathrm{Cr}$ & $\mathrm{Al}, \mathrm{Cr}$ & $\mathrm{Al}, \mathrm{Cr}, \mathrm{Y}, \mathrm{La}, \mathrm{Ce}$ \\
\hline Improve hot corrosion resistance & La, Y & La, Y, Th & La, Th \\
\hline Sulfidation resistance & $\mathrm{Cr}$ & $\mathrm{Cr}$ & $\mathrm{Cr}, \mathrm{Co}, \mathrm{Si}$ \\
\hline Improves creep properties & $\mathrm{B}$ & - & $\mathrm{B}, \mathrm{Ta}$ \\
\hline Increases rupture strength & $\mathrm{B}$ & $\mathrm{B}, \mathrm{Zr}$ & $\mathrm{B}^{* * *}$ \\
\hline Grain-boundary refiners & - & - & $\mathrm{B}, \mathrm{C}, \mathrm{Zr}, \mathrm{Hf}$ \\
\hline Facilitates working & - & $\mathrm{Ni}_{3} \mathrm{Ti}$ & - \\
\hline
\end{tabular}

* Not all these effect necessarily occur in a given alloy.

** Hardening by precipitation of $\mathrm{Ni}_{3} \mathrm{Ti}$ also occurs if sufficient $\mathrm{Ni}$ is present.

*** If present in large amounts, borides are formed. 


\subsection{Phases in Ni-base superalloys}

The most common phases present in nickel base superalloys are listed below.

- Gamma matrix, $\gamma$, is a nonmagnetic matrix in an disordered FCC (Face Centred Cube) nickel-base phase which usually contains high amounts of solid-solution elements e.g., cobalt, iron, chromium, molybdenum and tungsten [25].

- Gamma prime, $\gamma^{\prime}\left(\mathrm{Ni}_{3} \mathrm{Al}, \mathrm{Ti}\right)$, being the main strengthening precipitate in Haynes 282, has an ordered FCC $\left(\mathrm{L}_{2}\right)$ crystal structure and is required for high-temperature strength and creep resistance. To precipitate $\gamma^{\prime}$ aluminium and titanium are required. $\gamma^{\prime}$ precipitates coherently with the $\gamma$ matrix [25], its crystal structure can be seen in Fig. 3.3, where the the corner atoms (blue) are $\mathrm{Al}$ or $\mathrm{Ti}$ and the surface atoms (grey) are Ni.

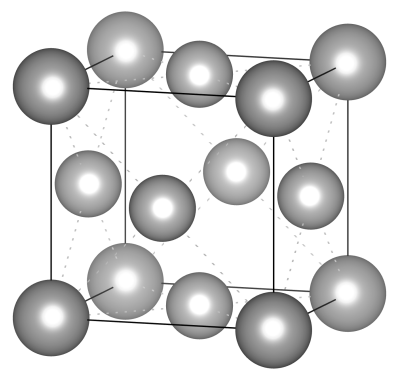

Figure 3.3. Crystal structure of the $\gamma^{\prime}$ phase [27].

- Gamma double prime, $\gamma$ ", has an ordered BCT (Body Centred Tetragonal) $\left(\mathrm{DO}_{2} 2\right)$ crystal structure and is most common in nickel-iron-base superalloys such as Inconel 718. In $\gamma$ " nickel and niobium form BCT $\mathrm{Ni}_{3} \mathrm{AlNb}$ in the presence of iron which is coherent with the $\gamma$ matrix. The $\gamma$ " phase induces large mismatch strains and provides high strength at temperatures up to $650{ }^{\circ} \mathrm{C}$ but becomes unstable at higher temperatures and transforms into $\delta$ phase over time.

- Delta phase, $\delta$, is common in nickel-iron-base superalloys such as Inconel 718. $\gamma$ " strengthened superalloys are susceptible to the formation of orthorhombic $\mathrm{Ni}_{3} \mathrm{Nb} \delta$ phase. The $\delta$ phase is the thermodynamically stable form of the metastable $\gamma$ " phase. In Inconel $718 \delta$ phase is formed in the temperature range $\sim 650{ }^{\circ} \mathrm{C}-980{ }^{\circ} \mathrm{C}[28]$ with a plate like morphology as seen in paper one [7]. 
- Grain-boundary, $\gamma^{\prime}$, can be achieved during heat treatments and when exposed to elevated temperatures during service. The grain-boundary $\gamma^{\prime}$ forms a film along the grain boundaries which in turn can prevent grain boundary dislocations. Though, it can become unstable during unwanted circumstances and instead of preventing dislocations it can become a low friction grain boundary film that is undesired [25].

- Carbides can precipitate when up to $0.2 \%$ of carbon is added and combined with carbide reactive elements e.g. titanium, tantalum, hafnium and niobium [25]. In Haynes 282 carbides exist in the form of grain boundary carbides, which helps to prevent grain boundary sliding. Some types of carbides can precipitate during extended periods of service subjected to sufficiently high temperatures. As a result, carbides can decompose, and generate other carbides e.g. $\mathrm{M}_{23} \mathrm{C}_{6}$ and/or $\mathrm{M}_{6} \mathrm{C}$, usually at grain boundaries. The "M" element is chromium, nickel, cobalt, iron, molybdenum, tungsten, niobium, hafnium, thorium, zirconium and tantalum [25]. Carbides are considered to have a beneficial effect on the rupture strength at high temperature, but also influence the ductility of the material [29].

- Borides are found in superalloys in the form of $\mathrm{M}_{3} \mathrm{~B}_{2}$, with a tetragonal unit cell. The boride particles are formed when boron segregates to grain boundaries. Small additions of boron are essential to improve creep rupture resistance in superalloys. Borides are hard particles, blocky to half moon in appearance, that are observed at grain boundaries [25].

- Topologically close packed (TCP) type phases, can be either plate or needlelike phases e.g. $\sigma, \mu$, and Laves, all which can cause a decrease in rupture strength and ductility. $\sigma$ phase has a tetragonal crystal structure, and is most common in iron- and cobalt-base superalloys. It usually appears as irregularly shaped globules due to long service times at temperatures between $540{ }^{\circ} \mathrm{C}$ and $980{ }^{\circ} \mathrm{C}$. The $\mu$ phase has a rhombohedral crystal structure and can be found in alloys with high molybdenum or tungsten content. It generally appears as coarse irregular Widmanstätten platelets that are formed at high temperatures. The Laves phase has a hexagonal crystal structure, it is most common in iron- and cobalt-base superalloys and appears as irregularly shaped globules or platelets when exposed to high temperatures for extended periods of time [30]. 


\section{CHAPTER 4}

\section{Experimental procedures}

In this chapter, the experimental methods used e.g. fatigue and microscopy are presented. The materials used were supplied by Siemens Industrial Turbomachinery AB and GKN Aerospace Engine Systems. The fatigue crack propagation testing and microscopy studies were performed at the Division of Engineering Materials at Linköping University.

\subsection{Inconel 718, KB test specimen experimental procedure}

In the first included paper the material used is standard heat-treated Inconel 718 according to AMS 5663; solution annealing for 1 hour at $945^{\circ} \mathrm{C}$, followed by ageing for 8 hours at $718{ }^{\circ} \mathrm{C}$ and 8 hours at $621^{\circ} \mathrm{C}$. With a chemical composition as shown in Table 4.1 and an average grain size of $10 \mu \mathrm{m}$.

Table 4.1. Composition of elements for Inconel 718.

\begin{tabular}{lllllllllllllll}
\hline Alloy & Wt \% & $\mathrm{Ni}$ & $\mathrm{Cr}$ & $\mathrm{Fe}$ & $\mathrm{Mo}$ & $\mathrm{Nb}$ & $\mathrm{Co}$ & $\mathrm{C}$ & $\mathrm{Mn}$ & $\mathrm{Si}$ & $\mathrm{S}$ & $\mathrm{Cu}$ & $\mathrm{Al}$ & $\mathrm{Ti}$ \\
\hline \multirow{2}{*}{ Inconel 718} & Min. & 50 & 17 & \multirow{2}{*}{ Bal. } & 2.8 & 4.75 & & & & & & & 0.2 & 0.7 \\
& Max. & 55 & 21 & & 3.3 & 5.5 & 1 & 0.08 & 0.35 & 0.35 & 0.01 & 0.3 & 0.8 & 1.15 \\
\hline
\end{tabular}




\subsubsection{Specimens}

In Fig. 4.1, a Kb-type test specimen is shown which was used for all tests. The Kb-type test specimen had a rectangular cross-section of $4.3 \times 10.2 \mathrm{~mm}$ with an electro-discharge machined starter notch measuring: depth $0.075 \mathrm{~mm}$, width 0.15 $\mathrm{mm}$, and length $0.3 \mathrm{~mm}$. For each test condition, one specimen was used.
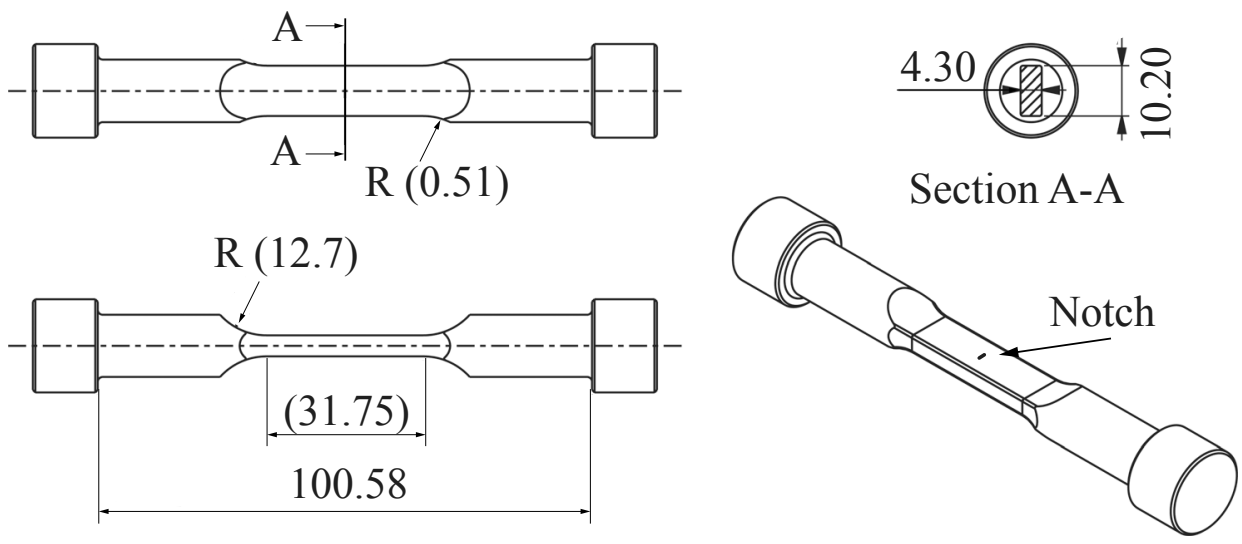

Figure 4.1. Drawing of the Kb-specimen with the rectangular cross section, dimensions in $\mathrm{mm}$.

\subsubsection{Testing setup}

Testing was done using a $160 \mathrm{kN}$ MTS servo hydraulic tensile/compression testing machine, equipped with a three zone high temperature furnace. A fatigue precrack was propagated in laboratory air at room temperature with the load ratio $R=0.05$, according to

$$
R=\sigma_{\text {min }} / \sigma_{d w e l l},
$$

where $\sigma_{\text {min }}$ and $\sigma_{\text {dwell }}$ are minimum and maximum stress levels, and a sinusoidal cyclic frequency of $10 \mathrm{~Hz}$ resulting in a semi-circular crack with a depth of approximately $0.2 \mathrm{~mm}$.

After pre-cracking high temperature testing was started. All dwell and overload tests were conducted in air with the test parameters shown in Table 4.2, the overload being calculated according to

$$
O L=\frac{\Delta P_{\text {unloading }}}{P_{\text {dwell }}},
$$

with $\Delta P_{\text {unloading }}$ and $P_{\text {dwell }}$ being loads defined in Fig. 4.2. 
Table 4.2. Summary of elevated temperature crack growth tests at: $550{ }^{\circ} \mathrm{C}$ with a nominal load of $650 \mathrm{MPa}$ and an $R$-ratio of 0.05 .

\begin{tabular}{cc} 
nominal load of $650 \mathrm{MPa}$ and an $R$-ratio of 0.05. \\
\hline Dwell-time $[\mathrm{s}]$ & Overload [\%] \\
\hline Cyclic, $0.5 \mathrm{~Hz}$ & - \\
2160 & - \\
2160 & $2.5 \%$ \\
2160 & $5 \%$ \\
2160 & $15 \%$ \\
\hline
\end{tabular}

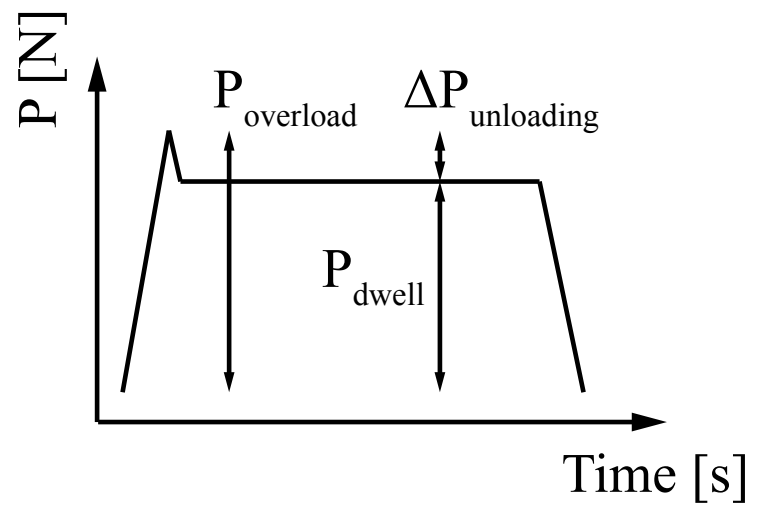

Figure 4.2. Schematic illustrating the overload cycle.

\subsubsection{Crack growth measurements}

Crack growth was measured according to ASTM E 647 using a 12 A channel pulsed DCPD (Direct Current Potential Drop) system. Crack length was calculated by dividing the potential drop (PD) over the crack by the PD on the opposite side of the sample as a reference. This ratio was then converted to crack length assuming a semi-circular crack front via an experimentally acquired calibration curve for Inconel 718 which showed the PD ratio as a function of crack length based on the initial and final crack lengths measured on the fracture surface as well as by measured induced beach marks [31]. The analytical solution for the stress intensity factor, $\mathrm{K}$, was obtained using a pre-solved case for a semi-elliptic surface crack according to ASTM E740-03. When a crack length of $2.5 \mathrm{~mm}$ was reached, according to the $\mathrm{PD}$ value, the test was interrupted. 


\subsection{Haynes 282, CT test specimen experimental procedure}

In the second included paper the material used was Haynes 282 delivered in the form of a forged ring, heat-treated accordingly: solution heat treated for 2 hours at $1100{ }^{\circ} \mathrm{C}$ then aged for 2 hours at $1010{ }^{\circ} \mathrm{C}$, with a final ageing treatment at $788^{\circ} \mathrm{C}$ for 8 hours. The material had a chemical composition as shown in Table 4.3 and an average grain size of $120 \mu \mathrm{m}$ or \# 3 according to ASTM-E112.

Table 4.3. Composition of elements for Haynes 282 in wt \%.

\begin{tabular}{lccccccccccccccc}
\hline Alloy & $\mathrm{Ni}$ & $\mathrm{Cr}$ & $\mathrm{Co}$ & $\mathrm{Mo}$ & $\mathrm{Ti}$ & $\mathrm{Al}$ & $\mathrm{Fe}$ & $\mathrm{Nb}$ & $\mathrm{C}$ & $\mathrm{Si}$ & $\mathrm{Mn}$ & $\mathrm{Cu}$ & $\mathrm{Ta}$ & $\mathrm{W}$ & $\mathrm{B}$ \\
\hline Haynes 282 & 56.9 & 19.6 & 10.3 & 8.7 & 2.24 & 1.5 & 0.5 & 0.1 & 0.06 & 0.05 & 0.04 & 0.01 & 0.01 & 0.01 & 0.005 \\
\hline
\end{tabular}

\subsubsection{Specimens}

Crack propagation tests were conducted using compact tension (CT) specimens with a width $W=25 \mathrm{~mm}$ and a full thickness $B=12.5 \mathrm{~mm}$. For all tests sidegrooves were used giving a net section thickness of $B_{n}=9.5 \mathrm{~mm}$. The specimens had an electro-discharge machined starter notch measuring $a_{n}=12.5 \mathrm{~mm}$

All were fatigue pre-cracked at room temperature to a crack length of $a_{0}=$ $16 \mathrm{~mm}$ using a sinusoidal cyclic test frequency of $10 \mathrm{~Hz}$, and a load range of $2500 \mathrm{~N}$ according to

$$
\Delta P=P_{\max }-P_{\min }
$$

and a load ratio of $R=0.1$ according to

$$
\Delta R=P_{\min }-P_{\max }
$$

All tests were performed according to ASTM E647 using the compliance method for crack length measurements at ambient temperature while the potential drop (PD) technique was used at elevated temperatures. The specimen and PD-instrumentation is illustrated in Fig. 4.3 (a) and a schematic rear- and side-view drawing in Fig. 4.3 (b) and (c) respectively. One specimen was used for each test condition. 
a)

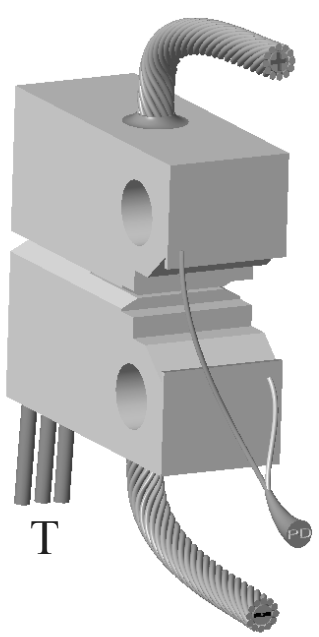

b)

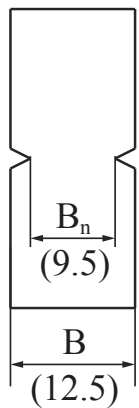

c)

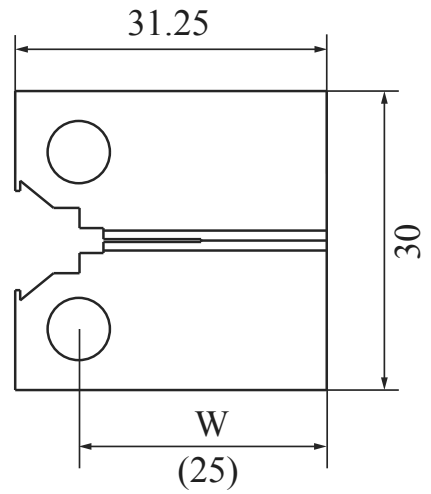

Figure 4.3. a) A 3D view of an instrumented CT specimen with side grooves. (b), (c) A schematic rear- and side-view drawing respectively, with all measurements given in $\mathrm{mm}$.

\subsubsection{Room temperature crack propagation test setup}

Room temperature fatigue crack propagation tests were performed using different stress ratios and frequencies. All tests were run with a load range of $2.5 \mathrm{kN}$. The crack opening displacement was measured using an Instron clip gauge extensometer and the crack growth rates were evaluated according to ASTM E647. Table 4.4 summarizes all the parameters used for the tests run at room temperature.

Table 4.4. Summary of room temperature fatigue crack growth tests run with a load range of $\Delta \mathrm{P}=2.5 \mathrm{kN}$.

\begin{tabular}{cc}
\hline Frequency $[\mathrm{Hz}]$ & $R$-ratio \\
\hline 0.05 & 0.1 \\
1 & 0.1 \\
15 & 0.1 \\
15 & 0.5 \\
\hline
\end{tabular}




\subsubsection{High temperature crack propagation test setup}

High temperature crack propagation tests were conducted with different dwelltimes (90 s and $2160 \mathrm{~s}$ ), as well as under sustained load conditions. Testing was done using a $100 \mathrm{kN}$ Zwick servo electric tensile testing machine (Kappa 50DS), equipped with a three zone (high temperature) furnace. Table 4.5 summarises all the parameters used for the tests run at elevated temperature. All tests were performed according to ASTM E647 using a 20 A pulsed direct current potential drop (DCPD) system where crack lengths were obtained by using the Johnson formula, according to

$$
a=\frac{2 W}{\pi} \cos ^{-1} \frac{\cosh \left(\frac{\pi y}{2 W}\right)}{\cosh \left[\frac{U}{U_{0}} \cosh ^{-1}\left(\frac{\cosh \frac{\pi y}{2 W}}{\cos \frac{\pi a_{0}}{2 W}}\right)\right]},
$$

were $U_{0}$ and $a_{0}$ are the initial values of the potential and the crack length, respectively, while $U$ and $a$ are the actual values of the potential and the crack length, $y$ is one half of the gauge span for $U$ and $W$ is the sample width.

Table 4.5. Summary of elevated temperature crack growth tests.

\begin{tabular}{cccc}
\hline Temperature & Loading condition & Load & $R$-ratio \\
\hline $650{ }^{\circ} \mathrm{C}$ & $90 \mathrm{~s}$ dwell-time & $\Delta P=3500 \mathrm{~N}$ & $R=0.05$ \\
$650{ }^{\circ} \mathrm{C}$ & $2160 \mathrm{~s}$ dwell-time & $\Delta P=3500 \mathrm{~N}$ & $R=0.05$ \\
$650{ }^{\circ} \mathrm{C}$ & Sustained load & $P=5000 \mathrm{~N}$ & - \\
$700{ }^{\circ} \mathrm{C}$ & Sustained load & $P=4500 \mathrm{~N}$ & - \\
$700{ }^{\circ} \mathrm{C}$ & Sustained load & $P=5000 \mathrm{~N}$ & - \\
\hline
\end{tabular}

The analytical solution of the stress intensity factor, $K$, for CT-specimens with side grooves was obtained from ASTM E399, according to

$$
K=\frac{P}{\sqrt{B \cdot b_{n} \cdot W}} f\left(\frac{a}{W}\right)
$$

where:

$$
\begin{aligned}
f\left(\frac{a}{W}\right)=\frac{1}{\left(1-\frac{a}{W}\right)^{3 / 2}}\left[2+\frac{a}{W}\right] & {\left[0.886+4.64\left(\frac{a}{W}\right)\right.} \\
& \left.-13.32\left(\frac{a}{W}\right)^{2}+14.72\left(\frac{a}{W}\right)^{3}-5.6\left(\frac{a}{W}\right)^{4}\right] .
\end{aligned}
$$

The tests were stopped at an approximate crack length of $20 \mathrm{~mm}$, after which some specimens were sectioned as-is, perpendicular to the centreline of the crack, so that the crack path could be studied in a cross-section. 


\subsection{Microscopy and image analysis}

For both included articles a Hitachi SU70 FEG analytical scanning electron microscope (SEM), operating at $1.5-20 \mathrm{kV}$ was used together with electron channelling contrast imaging (ECCI) [32] to get high quality, high contrast pictures of the crack growth appearance and the microstructure as seen in Fig. 4.6. Some specimens were cross-sectioned and mounted as-is, so that the crack path could be studied, while others were tensiled until fracture and used for studying the fracture surfaces. The cross-sectioned specimens were cut roughly at the centreline of the crack.

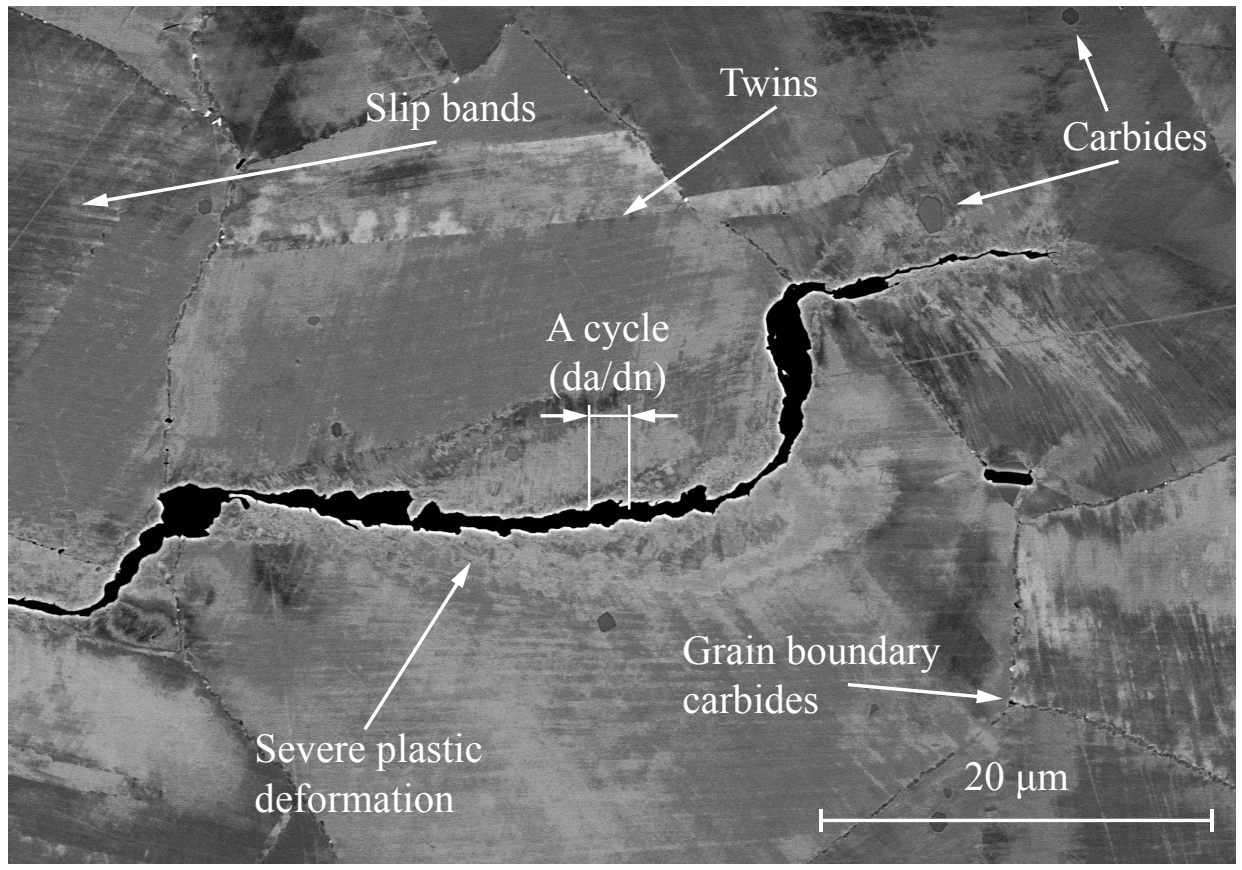

Figure 4.4. An ECCI image of Haynes 282 subjected to pure cyclic fatigue (sinusoidal wave) at room temperature , $0.05 \mathrm{~Hz}$, and $R=0.1$, showing how channeling can be used to illustrate e.g. plastically deformed areas.

\subsubsection{Electron channelling contrast imaging}

ECCI is based on the fact that backscattered electron intensity is strongly dependent on the orientation of the crystal lattice planes with respect to the incident electron beam. This enables us to observe microstructural features with different crystal lattice orientations, such as grains, subgrains, twins, dislocations and deformation.

The ECCI technique has been well known now for a long time, but to be able to use it, took quite some time (began in the seventies). It started with 
investigations done on single crystals, and was later used to look at dislocations in metals deformed due to fatigue and/or cracks.

To use the ECCI technique is quite limiting, the main reason being well controlled diffraction conditions are required as dislocation imaging is obtained by orienting the crystal matrix exactly into the Bragg condition [33] according to

$$
n \lambda=2 d \sin \left(\theta_{B}\right),
$$

for a selected set of diffracting lattice planes were $n$ is a positive integer, $\lambda$ is the wavelength of incident wave, $d$ is the interplanar distance and $\theta_{B}$ is the scattering angle.

As previously mentioned ECCI makes use of the backscattered electron intensity, and is strongly dependent on the orientation of the crystal lattice planes with respect to the incident electron beam due to the electron channeling mechanism, illustrated in Fig. 4.5. This means that local distortions in the crystal lattice due to dislocations can cause changes in the backscattered electron intensity, making it possible to image defects. ECCI has been used to image dislocation structures in metals deformed during fatigue and fracture, to quantitatively characterise dislocation structures (e.g. Burgers vector analysis), and to image varying structures with optimal contrast. At this point in time ${ }^{1}$ the only method employed for performing ECCI of dislocations under controlled diffraction conditions is based on electron channeling patterns (ECPs). The main technical drawback being the requirement of a large final aperture to allow the beam to cover a large angular regime, resulting in a very low spatial resolution (above $2 \mu \mathrm{m}$, almost two orders of magnitude above the resolution of electron backscattered diffraction (EBSD)) [34]. This frailty reduces its application to the imaging of dislocation structures in lightly deformed metals.

\section{The origin of ECCI}

In 1967, Coates [35] observed "Kikuchi like" bands while using a regular SEM when taking images of single crystals. He noticed that these "Kikuchi like" bands were produced at low magnification, this meant that there was an angular dependence with the scanning mechanism that resulted in these patterns. This mechanism was defined as electron channeling. At almost the same time Booker et al. [36] suggested that these "Kikuchi like" bands could be explained by the superposition of two Bloch waves (Bloch waves is a type of wave function for a particle in a periodically-repeating environment, a.k.a. an atom in a lattice). Booker et al. also predicted the possibility of observing subgrain boundaries and dislocations at high magnification using ECCI. In 1971, Spencer et al. [37] developed a dynamical many beam Bloch wave approach which took into account multiple scattering between forward and backscattered intensities. The cool thing was that it predicted the disappearance of channeling bands related to the vanishing of diffraction spots in transmission electron microscopy (TEM) diffraction patterns due to double diffraction. Sandström et al. [38] proposed another dynamical many

\footnotetext{
${ }^{1}$ As I sit here writing this thesis.
} 
beam approach in 1973 which took into account the energy losses due to single electron excitations and plasmons. This explained why the contrast to noise ratio of ECCI depends on the magnitude of the energy window.

\section{How ECCI works}

The term "channeling contrast" is used to describe the ECP contrast. Maximum contrast occurs due to the same electron-electron inelastic scattering processes that is used to image Kikuchi bands in TEM. In the beginning when ECCI was discovered, the term Kikuchi line was basically only used by TEM-users. The ECP's imaged in an SEM by Booker et al. [36] called them "inverse channeling patterns" because ECP's were more comparable to proton channeling patterns observed at the time [32].

Channeling is used to describe the movement of charged particles inside a crystalline lattice. This is the easiest way to look at and explain orientation contrast and defect contrast qualitatively. A crystalline lattice consists of lattice points oriented in the best case scenario in perfect rows and columns. The empty space between these lattice point could be described as channels where a particle can penetrate deeper before scattering as can be seen in Fig. 4.5.

At low magnifications the scanning of the electron beam enables several channels to be accessed over a wide angular range. The angular scanning of the beam

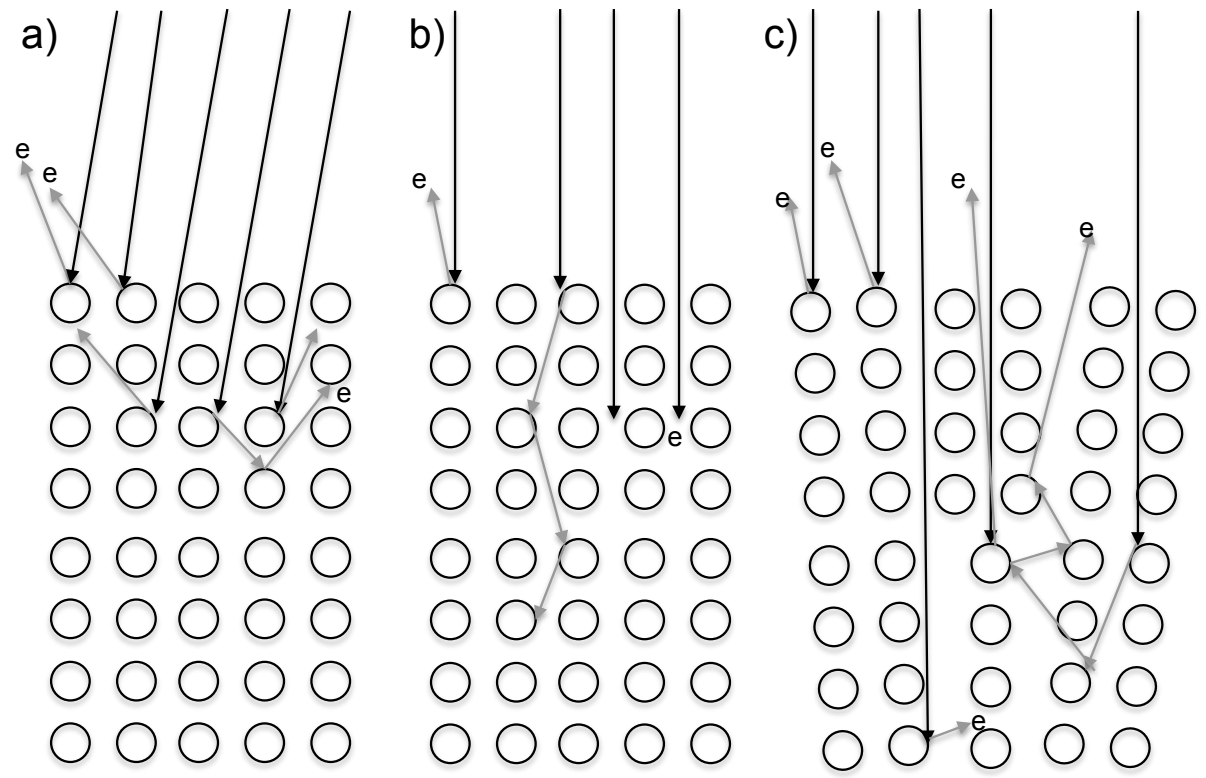

Figure 4.5. Channeling contrast illustration of the channeling effect during the: (a) "closed channel" condition. (b) "open channel" condition and in (c) dislocations can locally change the channeling condition between "open channel" and "closed channel". 
results in variations in backscattered electrons and the generation of ECP's. If magnified enough a single "channel" could be looked at. If this would be accomplished and there would not be any dislocations present altering the "channel" we should end up with zero contrast, and it should give a constant signal.

Currently there are no perfect materials, single- or polycrystalline, at least to my knowledge, therefore preexisting or induced crystal defects such as dislocations and or stacking faults will block the channels and should result in the scatter of more electrons back towards the detector as seen in Fig. 4.5 (c).

Or in the opposite case, a dislocation could open up a channel and enable electrons to penetrate deeper, resulting in less electrons that scatter back and being detected. However you might look at it we end up with an effect of dislocation contrast through electron channeling.

For the reader who wants a more scientific explanation the following might suffice. The ordered structure of atoms in crystalline solids usually influence the back scattering of electrons. If a well-collimated electron beam is directed at a crystal lattice, the density of atoms that the beam encounters will differ with the crystal orientation. In certain directions, where the atomic density is very low, socalled "channels" can be found, these channels are what enables the beam electrons to penetrate more deeply into the crystal before starting to scatter. When beam electrons penetrate deeper into the crystal, the probability that they will return to the surface as backscattered electrons is reduced. For other crystal orientations, a denser atom packing is found, and the beam electrons begin to scatter immediately at the surface, increasing the backscatter coefficient according to

$$
\eta=\frac{\eta_{B S E}}{\eta_{B}}
$$

where $\eta$ is the backscatter coefficient, $\eta_{B S E}$ are the number of backscattered electrons, and $\eta_{B}$ are the beam electrons incident on the specimen [39]. The modulation of the backscatter coefficient between the maximum and the minimum channeling cases is small, only about $5 \%$ difference [40]. Even though it is a small difference, this crystallographic or electron channeling contrast can be used to derive microstructural information of crystalline materials [40]. The probability for channeling is estimated with the Bragg diffraction relation according to Eq. (4.8).

So what is the difference between ECP and EBSD patterns? Well the wide angular collection of electrons by a (phosphor screen) EBSD detector, Fig. 4.6 (a), can be compared with the large angular width of the electron beam scanning via low-magnification imaging for ECP [32] detected with a diode detector, as can be seen in Fig. 4.6 (b).

A significant difference between EBSD patterns and ECP is that EBSD informs us about the specimen orientation relative to the detector and ECP informs us of the specimen orientation relative to the incoming electron beam [32]. 
a)

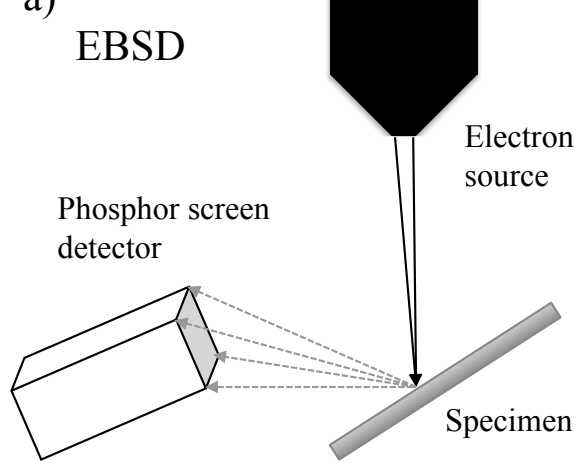

b)

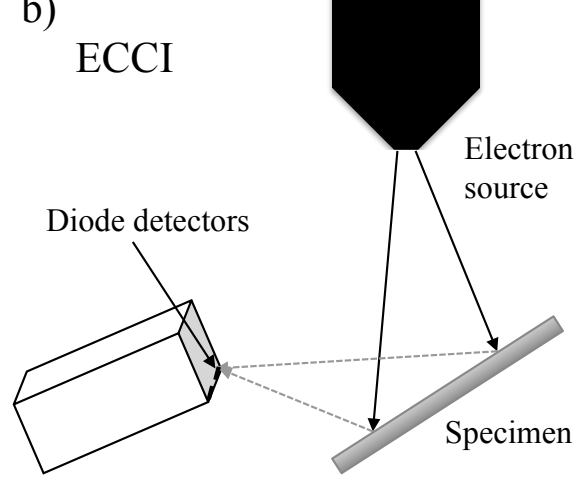

Figure 4.6. Illustrating the difference between (a) EBSD and (b) ECCI.

\subsection{Potential drop}

There are two main types of potential drop measuring methods, the direct current potential drop method (DCPD) which depends on the resistivity of the specimen and the alternating current potential drop (ACPD) method which instead relies on the specimen impedance (skin effect). It is the pulsed DCPD method that has been used through all the investigations of crack propagation in this thesis (because it is less sensitive than ACPD, when it comes to mounting) and will be described in short.

The direct current potential drop technique works by the principle that an electrically conductive specimen is used. When a current is passed through the specimen it will show a voltage drop across its cross-sectional surface when the specimen starts to crack as a result of the smaller cross-sectional area. If the resistance of the specimen is known, the voltage drop can be calculated for any particular value of the current. The specimen resistance will change when a defect is introduced e.g. a crack. This means that, by maintaining a constant current through the specimen, enables the possibility to detect both crack initiation as well as crack propagation, by monitoring the potential drop.

The DCPD and ACPD methods have been in use for decades. DCPD was the first method to be used due to its simplicity. In the early 1980's ACPD started catching up and gained interest due to better sensitivity when conducting crack measurements. As time goes by technology advances as well, which lead to the development of the pulsed DCPD and reversing DCPD which in turn improved the sensitivity of the DCPD systems. During the mid 1990's microprocessor control and more advanced electronics were developed which removed the sensitivity difference between the DCPD and ACPD methods.

Both the DCPD and ACPD methods entail at least four specimen connections. Two for the current and the other two for measuring the potential drop. Two extra connections can also be used as a reference point on the test sample (meaning a reference point on the sample which is unaffected by the crack), as seen in Fig. 4.3. 


\section{DCPD}

When a direct current passes through a specimen, it is usually assumed that the current is spread out evenly through the bulk of the material at the same instant when the current is applied. To get a good measurable signal (good being a signal with a good signal to noise ratio) large currents are usually required. The typical current range used for DCPD is 10-50 amps. Continuous direct current can be used but it can also result in "self-heating" which in turn might alter the specimen resistivity and in the end the measured DCPD. The "self-heating" problem can easily be fixed by using the pulsed DCPD method, where the current is pulsed on and held for a short period of time before being turned off again. When the pulsed signal is on the signal is also recorded.

When measuring crack length via DCPD the crack length signal changes in a non linear fashion due to remaining ligaments/islands witch tend to "shorten the total crack length". This makes the DCPD method slightly less sensitive to short cracks and crack initiation. In theory the DCPD response is linear which makes calibration easier, but this is a simplification and usually calibration is done by using beach-mark testing and/or interrupted tests.

Although DCPD is non-linear the crack length can be approximated using the Johnson equation as seen in Eq. (4.5).

The pulsed DCPD method was used for all crack propagation measurements at high temperature. The main difference in the pulsed DCPD setups between the KB-samples and CT-samples where that as mentioned previously two extra connections on the back of the KB-sample was used as a reference. In the case of the CT-samples the pulsed DCPD signal was instead converted to crack length according the Johnson equation. 


\section{CHAPTER 5}

\section{Crack propagation}

Fatigue crack propagation is one of the major problems being dealt with on a day to day basis. Vast amounts of research and plenty of books have been written about the subject. This does not mean in any way that all problems have been solved. Components being used in different hazardous environments and other applications usually increase the fatigue rate. A life prediction model for the overload tests microstructuraly investigated by the author in [7] was developed by Gustafsson et al. in [31] and for the other test series leading up to it are discussed in [31, 41-52] where models for fatigue crack propagation modified to handle e.g. load ratios $R$, stress-intensity factors $K$, threshold values and environmental effects, which are vital to accurately enable life prediction.

Many models today can be used to estimate the life of components under very specific conditions, but in reality it is very hard to accurately estimate the life of components, at least with the already preexisting models available. Modelling is of course important, but more so is the understanding and possibility to explain the leading mechanisms behind the crack propagation during fatigue.

Nickel-base superalloys such as Inconel 718 and Haynes 282 have shown time dependent crack growth behaviour at elevated temperatures $\left(>500{ }^{\circ} \mathrm{C}\right)$, and have been reported in both included papers of this thesis. Therefore the main mechanisms contributing to time dependent crack growth behaviour at elevated temperatures will be discussed here. 


\subsection{Dynamic embrittlement}

The use of wrought fine grained polycrystalline nickel-base superalloys, such as Inconel 718, are in many situations limited by their susceptibility to expeditious intergranular cracking during prolonged dwell times at high temperatures and high tensile stresses [42]. It has been well established that time dependent intergranular cracking of nickel-base superalloys, under both sustained and cyclic loads, is dominated by environmental interactions with oxygen at the crack tip [53, 54]. Intergranular cracking is not due to the formation of massive oxidation products along the grain boundaries. The mechanism is better described as nano scaled dynamic embrittlement (DE), where oxygen diffuses into highly stressed grain boundaries at the crack tip and mainspring decohesion $[55,56]$. Previous studies $[41,57,58]$ have shown that Inconel 718 mainly cracks transgranularly during cyclic testing in the lower temperature range and intergranularly during fatigue and dwell-fatigue at higher temperatures. The same behaviour has been perceived in other superalloys such as Waspalloy [43]. Grain boundary embrittlement has been studied in $[43,44,54]$ where it was shown that the crack growth per cycle during unloading-reloading is much higher after a dwell time period compared to pure cyclic loading. Similar observations has been reported to occur during thermomechanical fatigue crack growth tests [42].

The DE mechanism was first mentioned in [59] as an explanation to the increase in crack growth when comparing cyclic crack growth with sustained and/or dwell time crack growth. DE is a time-dependent brittle, intergranular fracture mechanism [60]. It is controlled by the diffusion of embrittling elements to grain boundaries as seen in Fig. 5.1.

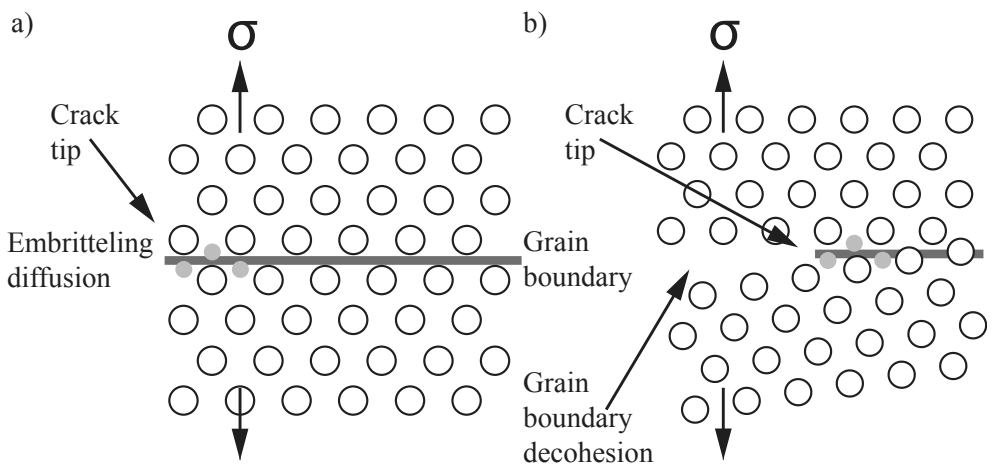

Figure 5.1. Schematic representation of the dynamic embrittlement mechanism where (a) is before cracking and (b) is after cracking.

These embrittling elements can be pre-existing in the alloy (e.g. sulphur-induced cracking in alloy steels [60]) or be supplied by the surrounding environment (e.g. oxygen induced cracking of nickel-base superalloys [60]). DE might be a generic damage mechanism [55] that occurs when all of the three following requirements are fulfilled: 
1. Embrittling species with low melting temperatures, either pre-existing in the alloy or from the surrounding atmosphere, adsorb at the free surface at the crack tip.

2. The temperature and the elastic stress ahead of the crack tip are high enough to enable grain boundary diffusion of the embrittling species. This is of more concern when looking at high-strength materials, since plastic deformation at the crack tip could cause stress relaxation, which could result in a diffusion retardation of the embrittling species.

3. The embrittling species lowers the grain boundary cohesion enough that crack growth can persevere.

Microstructure can significantly impact the DE process. A microstructure consisting of large grains is more prone to higher grain boundary stress concentrations and usually show a shorter and less tortuous crack appearance. The DE fracture mechanism is not only determined by grain size but also by the crystallographic misorientation relationship [55]. As DE sets in, the build up of diffused species start to aid in the decohesion process and and when this build up has reached a high enough level, oscillating macroscopic crack propagation can begin. The oscillation can be explained by a selective intergranular diffusion process depending on the geometry and structure of the grain boundaries [55]. After which creep and plastic rupture of uncracked ligaments increase the crack tip stress intensity resulting in intergranular fracture. To improve the resistance against DE of polycrystalline Ni-base alloys small additions of B, C, Hf or Zr, which may improve the grain boundary strength by lowering either the grain boundary energy or the embrittlement diffusivity, can be used [61]. How grain size and morphology fully effects crack propagation is not fully understood.

Fig. 5.2 adapted from [62] shows how dwell time crack growth, creep, tensile, and Low cycle fatigue (LCF) properties change with an increasing grain size for Udimet 720. A reduction in both tensile strength and LCF is a result of the larger grain size, but the larger grain size does not only have detrimental effects, it significantly improves the resistance against dwell-time crack growth and its creep properties.

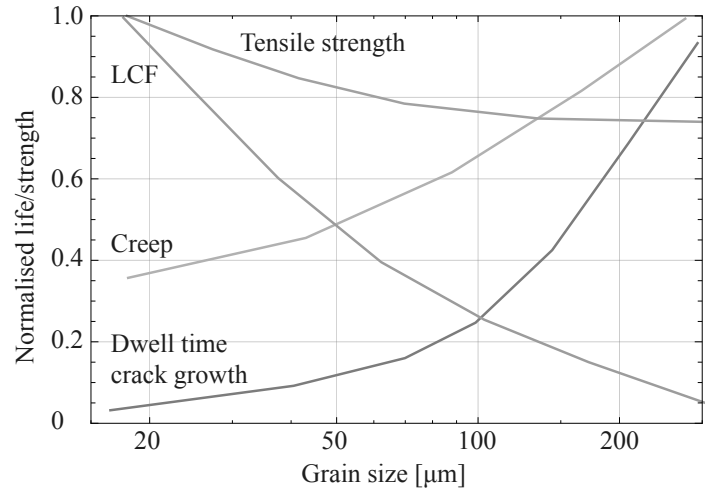

Figure 5.2.

Normalised life and strength vs. grain size, adapted from [62]. 


\subsection{Stress accelerated grain boundary oxidation}

Stress accelerated (sometimes also termed strain-assisted [63]) grain boundary oxidation (SAGBO) is an environmentally assisted crack growth mechanism suggested to be either a partial or the leading mechanism for crack growth in alloys tested in air. The SAGBO mechanism was first reported in [64], in which it was called "stress-corrosion cracking". The paper by Carpenter et al. [65] is one of the first papers discussing SAGBO in connection with crack propagation. In [66] Li et al. suggested that the sustained load crack growth in RR1000 at $700{ }^{\circ} \mathrm{C}$ takes place by a mechanism similar to DE by repeated fracture of an oxide film in the grain boundary ahead of the crack, namely SAGBO. Such films, with penetration depths of around 1-10 $\mu \mathrm{m}$ ahead of the tip, have been observed in dedicated experiments in several Ni-base superalloys $[63,67,68]$. The SAGBO crack propagation mechanism has been discussed and suggested as a possible crack propagation mechanism in in several other papers such as [54, 55, 59, 69-77]. In [53] a good explanation (well written and understandable) of the differences between DE and SAGBO is given. In [61] ways of protecting against SAGBO by grain boundary chemistry modifications using boron is discussed.

The SAGBO crack propagation mechanism works as a result of grain boundary oxidation which then cracks and exposes new surfaces for further oxidation and subsequent cracking, as illustrated in Fig. 5.3.

Figure 5.3. Schematic representation of the tress accelerated grain boundary oxidation (SAGBO) mechanism.

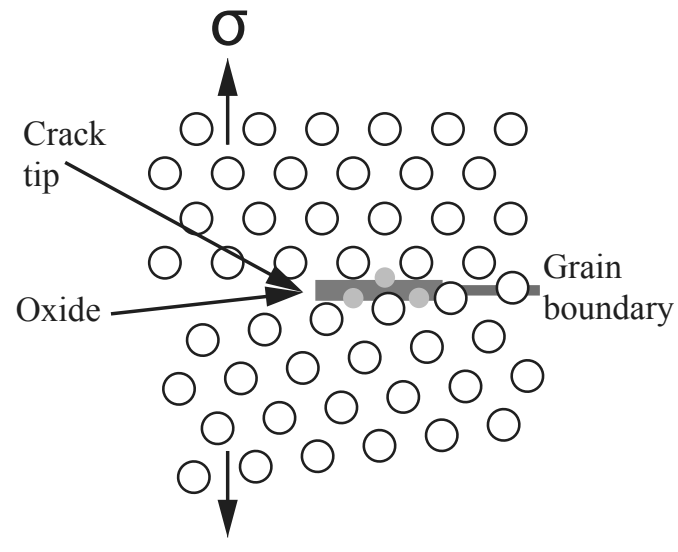

\subsection{Brittle/cleavage striations}

Fatigue striations are commonly found on fracture surfaces of various alloys ranging from Al-alloys to Ni-base superalloys. In general there are two types of fatigue striations, plastic and brittle striations [78-80]. Brittle striations are also called cleavage striations [81] in some literature. The mechanism behind striation formation can generally be explained as a two-step process. The first step being the result of crack-tip blunting during the loading part of a fatigue cycle, followed 
by a resharpening of the crack tip during the load reversal. Striations are more commonly observed in air than in vacuum. The lack of striations on fracture surfaces of metals tested in vacuum are due to oxides reducing slip reversal during crack closure. When fatigued in hard vacuum, slip can be almost be reversed completely. Both types of striations are transgranular. Ductile striations are called ductile because the material ahead of the crack tip undergoes plastic deformation that results in the typical curved arrays by which they advance on the fracture surface [82] as seen in Fig. 5.4 (a). Brittle striations, form in two steps, first by cleavage followed by crack-tip blunting and dislocation generation, and appear as concentric circles starting from an initiation point, often brittle inclusions, Fig. 5.4 (b). This is why brittle striations typically show a flat appearance with no real signs of plastic deformation. Brittle striations are always associated with corrosion assisted fatigue and, in particular, with hydrogen absorption [82]. The striation formation depends on the combination of cleavage as a result of local shear stress [81]. Brittle striations were observed in Haynes 282 in paper two. These observations are very similar to the striations observed during environmental hydrogen embrittlement of Ti-alloys [83-86]. In Ti-alloys, the brittle striations have been proposed to be due to the repeated stress assisted formation and fracture of hydride films ahead of growing cracks [84]. The crack growth behaviour in gaseous hydrogen exhibited similar behaviour as Haynes 282 in paper two, including the threshold above where an increased environmental effect could be observed [85, 86]. The difference between plastic and brittle striations can be seen in 5.4 (a) and $(b)$.
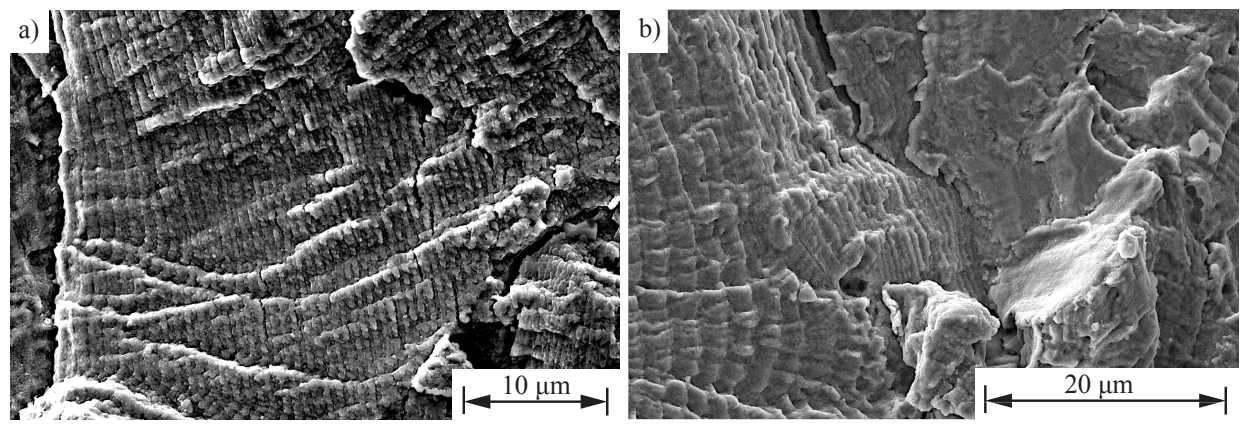

Figure 5.4. Fracture surfaces of the $90 \mathrm{~s}$ dwell-time sample in paper two (a) Fatigue striations. (b) Brittle striations.

\subsection{Crack tip blunting}

Crack tip blunting can occur when the plastic zone ahead of the crack tip grows large enough [87] so that it starts behaving like a notch [88] with a lower stress concentration than that of the originally sharp crack tip. Blunting of the crack tip will impede the crack growth rate since the energy needed to propagate a blunted crack tip is higher compared to a sharp crack tip. The blunting mechanism and 
its retarding affect on crack growth has been investigated in several papers $[7,53$, 89-92], discussing its affect during different loading conditions such as fatigue and creep fatigue, and has been modelled in [93].

\subsection{Other mechansims}

Other crack growth mechanisms, such as dynamic recrystallization, strain localization in persistent slip bands, deformation bands, and vacancy diffusion, have also been proposed as possible culprits for aiding crack propagation in references [94-98]. 


\section{CHAPTER 6}

Summary

Fatigue crack growth testing has been performed on Inconel 718 at $550{ }^{\circ} \mathrm{C}$ in paper one with the purpose of investigating the effect of overloads on dwell-fatigue crack growth. In paper two fatigue crack growth testing was performed on Haynes 282 at room temperature as well as at $650{ }^{\circ} \mathrm{C}$ and $700{ }^{\circ} \mathrm{C}$ under different loading conditions. The purpose of paper two was to clarify a number of controversial results previously reported for the same material, and to study the effects of dwell-fatigue and sustained loads on the crack growth behaviour.

To summarise the results from both papers the following conclusions can be made:

- Both Inconel 718 and Haynes 282 showed an increase in crack growth rate when dwell-times were introduced at the maximum load (0\% overload) in the fatigue cycle. With the introduction of a dwell-time; crack growth shifted from transgranular to intergranular, this was also shown in paper two as the result of a transition from cycle-dependent to time-dependent crack growth.

- When an overload was introduced at the beginning of the dwell-time in Inconel 718, the dwell-time effect was retarded. At an overload of $15 \%$, the dwell-time effect was essentially extinguished and the crack growth rate became the same as during pure fatigue loading without a dwell-time, accompanied by a transition from intergranular to transgranular cracking. At no or low overloads, high resolution scanning electron microscopy revealed that microscopic crack growth in Inconel 718 at high temperature took place as intergranular crack growth along grain boundaries due to oxidation and the creation of nanometric voids. Another observed growth mechanism was crack advance along $\delta$ phase boundaries with subsequent severe oxidation of 
the $\delta$ phase. Unbroken ligaments were observed behind the crack front. At such locations, the crack eventually grew along the substructures created by severe local plastic deformation and the high temperature. This substructure consisted, of dislocation sub-cells or nano-sized grains created by embryos to dynamic recrystallisation.

- For Haynes 282 some controversial results have been previously published claiming frequency dependence at room temperature which was not observed in the dwell-time tests conducted for paper two. More so it was shown to be stress ratio dependent at room temperature. At elevated temperatures the crack growth rate was shown to be purely time-dependent at stress intensity factors above $\sim 45 \mathrm{MPa} \sqrt{\mathrm{m}}$. The leading mechanism controlling the timedependent crack growth was suggested to be caused by stress-assisted grain boundary oxidation rather than dynamic embrittlement. 


\section{Bibliography}

[1] M. P. Boyce. "An Overview of Gas Turbines". In: Gas Turbine Engineering Handbook Second eddition. 2nd ed. Gulf Professional Publishing, 2002, pp. 3-3.

[2] W. Jörgensen et al. "Gasturbiner". In: Metall industrins handbok. Ed. by A. Lindell. 9th ed. Stockholm: Teknografiska Institutet, 1960. Chap. IX, pp. 337-338.

[3] R. Reed. "The requirement: the gas turbine engine". In: The superalloys fundamentals and applications. Cambridge University Press, 2008. Chap. 1.2, p. 12.

[4] R. Reed. "Characteristics of high-temperature materials". In: The superalloys fundamentals and applications. Cambridge University Press, 2008. Chap. 1.1.1, p. 1.

[5] R. Stake and T. Axinge. "Materialprovning". In: Almmän materiallära. Malmö: Hermods-NKI, 1966. Chap. Brev 3, p. 3.1.

[6] M. E. Fine. "Fatigue resistance of metals". In: Metallurgical Transactions A 11.3 (1980), pp. 365-379.

[7] J. Saarimäki et al. "Influence of overloads on dwell time fatigue crack growth in Inconel 718". In: Materials Science and Engineering: A 612 (2014), pp. 398405.

[8] M.P. Boyce. "Gas Turbine Engineering Handbook". In: pp. 15 -16.

[9] R. Reed. "The requirement: the gas turbine engine". In: The superalloys fundamentals and applications. Cambridge University Press, 2008. Chap. 1.2, pp. 8-13.

[10] T. Giampaolo. "Combustors". In: Gas Turbine Handbook Principles and Practices. 4th ed. The Fairmont Press, Inc., 2009, p. 35.

[11] S. Engelson, E. AF Geijerstam, and R. Lind. "Egentliga gasturbiner". In: Beskrivande Maskinlära. Malmö: Hermods-NKI, 1967. Chap. Brev 2, p. 50. 
[12] Siemens Industrial Gas Turbines AB. Combined cycle. 2015.

[13] Siemens Industrial Gas Turbines AB. Meet the SGT-750, 2010, pp. Product information about the SGT-750. Tech. rep. 2010.

[14] M. J. Donachie and S. J. Donachie. "Superalloys for High Temperatures". In: Superalloys: A Technical Guide. 2nd Editio. 2002. Chap. 1.

[15] "Elevated-temperature characteristics of engineering materials". In: ASM Specialty Handbook: Heat-Resistant Materials. ASM International, 1997. Chap. 1, p. 6.

[16] Special Metals Corp., Product Handbook of Product Handbook of HighPerformance Nickel Alloys.

[17] Haynes International Inc., Haynes 230 alloy product info. 2009.

[18] Haynes International Inc., Haynes 282 alloy product info. 2008.

[19] J.R. Davis, ed. ASM Specialty Handbook: Heat-Resistant Materials. 1997.

[20] R. Reed. The Superalloys Fundamentals and Applications. 2008.

[21] C. T. Sims, N. S. Stoloff, and W. C. Hagel. Superalloys II: High-Temperature Materials for Aerospace and Industrial Power. 2008.

[22] W. Hume-Rothery, R. E. Smallman, and C. W. Haworth. "Interstitial phases based on the F.C.C. metal atom structure". In: The structure of metals and alloys. 1st ed. London, 1969. Chap. 5.6, pp. 264-265.

[23] R. Reed. "Historical development of the superalloys". In: The superalloys fundamentals and applications. Cambridge University Press, 2008. Chap. 1.3.2, pp. 23-24.

[24] M. J. Donachie and S. J. Donachie. "Basic metallurgy of superalloys". In: Superalloys a technical guide. 2nd Editio. 2002. Chap. 1, pp. 6-7.

[25] "Metallurgy, processing, and properties of superalloys". In: ASM Specialty Handbook Heat-Resistant Materials. ASM International, 1997. Chap. 3, pp. 224231.

[26] R. Reed. "Other phases in superalloys". In: The superalloys fundamentals and applications. Cambridge University Press, 2008. Chap. 2.1.3, pp. 51-53.

[27] K. Momma and F. Izumi. "VESTA 3 for three-dimensional visualization of crystal, volumetric and morphology data". In: Journal of Applied Crystallography 44.6 (2011), pp. 1272-1276.

[28] E. E. Brown and D. R. Muzyka. "Nickel-iron alloys". In: Superalloys II Hightemperature materials for aerospace and industrial power. Ed. by Chester T. Sims, Norman S. Stoloff, and William C. Hagel. New York: Wiley, 1987. Chap. 6, pp. 180-181.

[29] E. W. Ross and C. T. Sims. "Nickel-base alloys". In: Superalloys II Hightemperature materials for aerospace and industrial power. Ed. by Chester T. Sims, Norman S. Stoloff, and William C. Hagel. New York: Wiley, 1987. Chap. 4, pp. 111-112. 
[30] E. W. Ross and C. T. Sims. "Nickel-base alloys". In: Superalloys II Hightemperature materials for aerospace and industrial power. Ed. by Chester T. Sims, Norman S. Stoloff, and William C. Hagel. New York: Wiley, 1987. Chap. 4, pp. 117-118.

[31] D. Gustafsson and E. Lundström. "High temperature fatigue crack growth behaviour of Inconel 718 under hold time and overload conditions". In: International Journal of Fatigue 48 (2013), pp. 178-186.

[32] R. J. Kamaladasa and Y. N. Picard. "Basic Principles and Application of Electron Channeling in a Scanning Electron Microscope for Dislocation Analysis". In: Microscopy: Science, Technology, Applications and Eduaction (2010), pp. 1583-1590.

[33] I. C. Noyan and J. B. Cohen. "Scatering from planes of atoms". In: Residual stress Measurement by diffraction and Interpretation. 1 st editi. SpringerVerlag, 1987. Chap. 4.9, p. 87.

[34] I. Gutierrez-Urrutia, S. Zaefferer, and D. Raabe. "Electron channeling contrast imaging of twins and dislocations in twinning-induced plasticity steels under controlled diffraction conditions in a scanning electron microscope". In: Scripta Materialia 61.7 (2009), pp. 737-740.

[35] D. G. Coates. "Kikuchi-like reflection patterns obtained with the scanning electron microscope". In: Philosophical Magazine 16.144 (1967), pp. 11791184 .

[36] G. R. Booker et al. "Some comments on the interpretation of the kikuchi-like reflection patterns observed by scanning electron microscopy". In: Philosophical Magazine 16.144 (1967), pp. 1185-1191.

[37] J. P. Spencer, C. J. Humphreys, and P. B. Hirsch. "A dynamical theory for the contrast of perfect and imperfect crystals in the scanning electron microscope using backscattered electrons". In: Philosophical Magazine 26.1 (1972), pp. 193-213.

[38] R. Sandström, J. F. Spencer, and C. J. Humphreysx. "A theoretical model for the energy dependence of electron channelling patterns in scanning electron microscopy". In: Journal of Physics D-Applied Physics 7 (1974), pp. 10301046 .

[39] J. I. Goldstein et al. "Backscattered electrons". In: Scanning electron microscopy and X-ray microanalysis. 2003. Chap. 3.4.1, p. 75.

[40] J. I. Goldstein et al. "Crystallographic contrast". In: Scanning electron microscopy and X-ray microanalysis. 2003, pp. 247-250.

[41] D. Gustafsson et al. "Fatigue crack growth behaviour of Inconel 718 with high temperature hold times". In: Procedia Engineering. Vol. 2. 10th International Fatigue Congress, FATIGUE 2010 1. 2010, pp. 1095-1104.

[42] J. Moverare and D. Gustafsson. "Hold-time effect on the thermo-mechanical fatigue crack growth behaviour of Inconel 718". In: Materials Science and Engineering A 528.29-30 (2011), pp. 8660-8670. 
[43] D. Gustafsson et al. "Fatigue crack growth behaviour of Inconel 718 - The concept of a damaged zone caused by high temperature hold times". In: Procedia Engineering. Vol. 10. 11th International Conference on the Mechanical Behavior of Materials, ICM11. 2011, pp. 2821-2826.

[44] D. Gustafsson et al. "Influence of high temperature hold times on the fatigue crack propagation in Inconel 718". In: International Journal of Fatigue 33.11 (2011), pp. 1461-1469.

[45] D. Gustafsson et al. "Modeling of the Constitutive Behavior of Inconel 718 at Intermediate Temperatures". In: Journal of Engineering for Gas Turbines and Power 133.9 (2011), p. 094501.

[46] D. Gustafsson, E. Lundström, and K. Simonsson. "Modelling of high temperature fatigue crack growth in Inconel 718 under hold time conditions". In: International Journal of Fatigue 52 (2013), pp. 124-130.

[47] E. Lundström et al. "A load history dependent model for fatigue crack propagation in Inconel 718 under hold time conditions". In: Engineering Fracture Mechanics 118 (2014), pp. 17-30.

[48] E. Lundström et al. "Modelling of Fatigue Crack Growth in Inconel 718 under Hold Time Conditions - Application to a Flight Spectrum". In: Advanced Materials Research 891-892 (2014), pp. 759-764.

[49] E. Storgärds and K. Simonsson. "Crack Length Evaluation for Cyclic and Sustained Loading at High Temperature Using Potential Drop". In: Experimental Mechanics 1 (2014).

[50] E. Storgärds et al. "Modeling of Crack Growth With Dwell Time for Aeroengine Spectra Loadings in a Ni-Based Superalloy". In: Journal of Engineering for Gas Turbines and Power 138.1 (2015), pp. 1-6.

[51] E. Storgärds et al. "Scatter in Dwell Time Cracking for a Ni-Based Superalloy in Combination With Overloads". In: Journal of Engineering for Gas Turbines and Power 138.1 (2015), pp. 1-7.

[52] E. Storgärds et al. "Thermomechanical Fatigue Crack Growth Modeling in a Ni-Based Superalloy Subjected to Sustained Load". In: Journal of Engineering for Gas Turbines and Power 138.1 (2015), pp. 1-7.

[53] D. A. Woodford. "Gas phase embrittlement and time dependent cracking of nickel based superalloys". In: Energy Materials: Materials Science and Engineering for Energy Systems 1.1 (2006), pp. 59-79.

[54] K. Wackermann, U. Krupp, and H. J. Christ. "Effects of the environment on the crack propagation behavior of IN718 in the temperature range of the dynamic embrittlement". In: ASTM Special Technical Publication. Vol. 1539 STP. ASTM International Symposium on Creep-Fatigue Interactions: Test Methods and Models. Siegen, Germany, 2011, pp. 297-312.

[55] U. Krupp. "Dynamic embrittlement - Time-dependent quasi-brittle intergranular fracture at high temperatures". In: International Materials Reviews 50.2 (2005), pp. 83-97. 
[56] E. G. Wagenhuber, V. B. Trindade, and U. Krupp. "The role of oxygengrain-boundary diffusion during intercrystalline oxidation and intergranular fatigue crack propagation in alloy 718". In: Proceedings of the International Symposium on Superalloys and Various Derivatives. Ed. by Loria E.A. 6th International Symposium on Superalloys 718, 625, 706 and Derivatives. Pitsburg, U.S., 2005, pp. 591-600.

[57] P. Heuler, E. Affeldt, and R. J. H. Wanhill. "Effects of Loading Waveform and Stress Field on High Temperature Fatigue Crack Growth of Alloy 718". In: Materialwissenschaft und Werkstofftechnik 34.9 (2003), pp. 790-796.

[58] J. P. Pédron and A. Pineau. "The Effect of Microstructure and Environment on the Crack Growth Behaviour of Inconel 718 Alloy at $650 \check{\text { rC } u n d e r ~ F a t i g u e, ~}$ Creep and Combined Loading". In: Materials Science and Engineering 56.2 (1982), pp. 143-156.

[59] C.T. Liu and C.L. White. "Dynamic embrittlement of boron-doped Ni3Al alloys at 600řC". In: Acta Metallurgica 35.3 (1987), pp. 643-649.

[60] R. W. Hertzberg, R. P. Vinci, and J. L. Hertzberg. "Dynamic Embrittlement". In: Deformation and Fracture Mechanics of Engineering Materials. 5th ed. 2012, p. 472.

[61] J. Röesler and S. Müller. "Protection of Ni-base superalloys against stress accelerated grain boundary oxidation (SAGBO) by grain boundary chemistry modification". In: Scripta Materialia 40.2 (1999), pp. 257-263.

[62] J. C. Williams and E. A. Starke Jr. "Progress in structural materials for aerospace systems". In: Acta Materialia 51.19 (2003), pp. 5775-5799.

[63] L. Viskari et al. "Intergranular crack tip oxidation in a Ni-base superalloy". In: Acta Materialia 61.10 (2013), pp. 3630-3639.

[64] C. J. Mcmahon and L. F. Coffin. "Mechanisms of Damage and Fracture in of a Cast High-Temperature, Low-Cycle Fatigue of a cast Nickel-Based Superalloy". In: Metallurgical Transactions 1.December (1970), pp. 34433450 .

[65] W. Carpenter, B. S. J. Kang, and K. M. Chang. "SAGBO Mechanism on High Temperature of Ni-base Superalloys Cracking Behavior". In: The Minerals, Metals and Materials Society (1997), pp. 679-688.

[66] H.Y. Li et al. "Effects of microstructure on high temperature dwell fatigue crack growth in a coarse grain PM nickel based superalloy". In: Acta Materialia 90 (2015), pp. 355-369.

[67] H. S. Kitaguchi et al. "Oxidation ahead of a crack tip in an advanced Nibased superalloy". In: Acta Materialia 61.6 (2013), pp. 1968-1981.

[68] L. Viskari, S. Johansson, and K. Stiller. "Oxygen influenced intergranular crack propagation: Analysing microstructure and chemistry in the crack tip region". In: Materials at High Temperatures 28.4 (2011), pp. 336-341.

[69] M. Hörnqvist et al. "High-temperature crack growth in a Ni-base superalloy during sustained load". In: Materials Science and Engineering: A 609 (2014), pp. 131-140. 
[70] X. Liu, L. Ma, and K. Chang. "Time-Dependent Crack Growth Behaviors of Five Superalloys". In: The minerals. Metals \& Materials Society (2001), pp. 543-552.

[71] X. Liu, B. Kang, and K. Chang. "The effect of hold-time on fatigue crack growth behaviors of WASPALOY alloy at elevated temperature". In: Materials Science and Engineering A 340.1 (2003), pp. 8-14.

[72] L. Viskari et al. "Grain boundary microstructure and fatigue crack growth in Allvac 718Plus superalloy". In: Materials Science and Engineering: A 528.6 (2011), pp. 2570-2580.

[73] H. E. Evans, H. Y. Li, and P. Bowen. "A mechanism for stress-aided grain boundary oxidation ahead of cracks". In: Scripta Materialia 69.2 (2013), pp. 179-182.

[74] F. A. Pérez-González, N. F. Garza-Montes-de Oca, and R. Colás. "High Temperature Oxidation of the Haynes 282 Nickel-Based Superalloy". In: Oxidation of Metals 82.3-4 (2014), pp. 145-161.

[75] K. Chang and X. Liu. "Effect of $\gamma$ content on the mechanical behavior of the WASPALOY alloy system". In: Materials Science and Engineering: $A$ 308.1-2 (2001), pp. 1-8.

[76] C. J. McMahon Jr. "Comments on "identification of SAGBO-induced damage zone ahead of crack tip to characterize sustained loading crack growth in alloy 783"'. In: Scripta Materialia 54.2 (2006), pp. 305-311.

[77] K. S. Chan. "A Grain Boundary Fracture Model for Predicting Dynamic Embrittlement and Oxidation-Induced Cracking in Superalloys". In: Metallurgical and Materials Transactions A 46.6 (2015), pp. 2491-2505.

[78] S. Suresh. "Models for striation formation". In: Fatigue of materials. 2nd ed. 1998. Chap. 10.2.3, pp. 337-340.

[79] S. Suresh. "Formation of brittle striations". In: Fatigue of materials. 2nd ed. 1998. Chap. 16.3.2, pp. 581-583.

[80] R. W. Hertzberg, R. P. Vinci, and J. L. Hertzberg. "Microscopic fracture mechanisms". In: Deformation and Fracture Mechanics of Engineering Materials. 5th ed. 2012, pp. 572-5745.

[81] "Mechanisms of fatigue striation formation". In: ASM Handbook, Fatigue and Fracture. 19th ed. 1997. Chap. 1, pp. 52-54.

[82] P. P. Milella. "Morphological Aspects of Fatigue Crack Formation and Growth". In: Fatigue and Corrosion in Metals. 2013. Chap. 2.4.2, pp. 97-100.

[83] H. G. Nelson, D. P. Williams, and J. E. Stein. "Environmental hydrogen embrittlement of an alpha-beta titanium alloy - Effect of microstructure." In: Metallurgical Transactions 3.2 (1972), pp. 473-479.

[84] H. G. Nelson. "A film-rupture modelof hydrogen-induced, slow crack-growth in acicular alpha-beta Titanium". In: Metallurgical Transactions 7.5 (1976), pp. $621-627$. 
[85] R. Gaddam et al. "Fatigue crack growth behaviour of forged Ti-6Al-4V in gaseous hydrogen". In: Corrosion Science 78 (2014), pp. 378-383.

[86] R. Gaddam et al. "Influence of high-pressure gaseous hydrogen on the lowcycle fatigue and fatigue crack growth properties of a cast titanium alloy". In: Materials Science and Engineering: A 612 (2014), pp. 354-362.

[87] R. H. Norris et al. "Fracture Mechanics, Damage Tolerance, and Life Assessment". In: ASM Specialty Handbook: Heat-Resistant Materials. 1997. Chap. 4, p. 371.

[88] S. Suresh. "Crack tip blunting". In: Fatigue of materials. 2nd ed. 1998. Chap. 14.12.2, pp. 522-523.

[89] F. Wang. "Mechanical property study on rapid additive layer manufacture Hastelloyő X alloy by selective laser melting technology". In: The International Journal of Advanced Manufacturing Technology 58.5-8 (2011), pp. 545551.

[90] J. A. Pfaendtner and C. J. Mcmahon JR. "Oxygen-induced intergranular cracking of a Ni-base alloy at elevated temperatures - an example of dynamic embrittlement". In: Acta Materialia 49.16 (2001), pp. 3369-3377.

[91] K. A. Rozman, J. J. Kruzic, and J. A. Hawk. "Fatigue Crack Growth Behavior of Nickel-base Superalloy Haynes 282 at 550-750 řC". In: Journal of Materials Engineering and Performance 24.8 (2015), pp. 2841-2846.

[92] A. Pineau and S. D. Antolovich. "High temperature fatigue of nickel-base superalloys - A review with special emphasis on deformation modes and oxidation". In: Engineering Failure Analysis 16.8 (2009), pp. 2668-2697.

[93] S. Ismonov et al. "Application of crack tip plasticity based fatigue model on high temperature alloy HAYNES 282". In: International Journal of Fatigue 70 (2015), pp. 146-153.

[94] K. Obergfell et al. "Effects of grain size and mechanical pretreatment on strain localization in FCC polycrystals". In: International Journal of Fatigue 23 (2001), pp. 207-214.

[95] D. J. Morrison, V. Chopra, and J. W. Jones. "Effects of grain size on cyclic strain localization in polycrystalline nickel". In: Scripta Metallurgica et Materialia 25.c (1991), pp. 1299-1304.

[96] P. A. S. Reed and J. E. King. "Mixed mode fatigue effects in Ni-base single crystals - Preliminary results". In: Scripta Metallurgica et Materialia 26.12 (1992), pp. 1829-1834.

[97] R. Rahouadj, J. Menigault, and M. Clavel. "Strain rate effects and associated deformation mode in a nickel-based alloy during low cycle fatigue testing". In: Materials Science and Engineering 93 (1987), pp. 181-190.

[98] S. Chen and G. Gottstein. "Strain softeneing, grain boundary migration and dynamic recrystallization of $\mathrm{Ni}$ during high temperature". In: Acta metall 36.12 (1988), pp. 3093-3101. 


\section{CHAPTER 7}

\section{Results and included papers}

The results obtained from my research leading up to this thesis are presented in the form of two scientific papers, one published and one currently under review with the Elsevier journal, Material Science \& Engineering A. 


\subsection{List of publications}

The following list is presented in chronologically descending order.

[I] Mechanical properties of lattice truss structures made of a selective laser melted superalloy

H. Brodin, J. Saarimäki

13th International Conference Fracture, Beijing, China.

[II] Influence of overloads on dwell time fatigue crack growth in Inconel 718

J. Saarimäki, J. Moverare, R. Eriksson, J. Johansson

Material Science \& Engineering A, 612, 398-405 (2014).

[III] Scatter in Dwell Time Cracking for a Ni-Based Superalloy in Combination With Overloads

E. Storgärds, J. Saarimäki, K. Simonsson, S. Sjöström,

D. Gustafsson, T. Månsson, J. Moverare

ASME. Journal of Engineering for Gas Turbines and Power, 138, 1, (2015).

[IV] Time dependent crack propagation in Haynes 282

J. Saarimäki, J. Moverare, M. Hörnqvist Colliander

Under review, Material Science 85 Engineering A.

[V] Impact of high cycle fatigue on dwell time crack growth in a $\mathrm{Ni}$ base superalloy

E. Storgärds, J. Saarimäki, K. Simonsson, S. Sjöström,

T. Månsson, J. Moverare

Submitted, International Journal of Fatigue. 


\subsection{Summary of included papers}

\section{Paper I}

Influence of overloads on dwell time fatigue crack growth in Inconel 718

\section{Summary}

Fatigue crack growth testing has been performed on Inconel 718 at $550{ }^{\circ} \mathrm{C}$ with the purpose of investigating the effect of overloads on the dwell-fatigue crack growth. We show that there is a significant increase in crack growth rate when dwell-times are introduced at the maximum load (0\% overload) in the fatigue cycle, and when an overload is applied prior to the dwell-time, the crack growth rate decreases with increasing overload levels.

\section{Author's contribution}

I performed parts of the mechanical testing and have been the main contributor regarding the microstructure investigation, evaluation, and responsible for the manuscript writing. The crack path analysis was done with the help of my coauthor PhD. Robert Eriksson.

\section{Paper II}

Time dependent crack propagation in Haynes 282

\section{Summary}

Crack growth tests were performed on Haynes 282 at room temperature as well as at $650{ }^{\circ} \mathrm{C}$ and $700{ }^{\circ} \mathrm{C}$ under different loading conditions. The purpose was to clarify a number of controversial results reported previously regarding $R$-value and frequency effects at room temperature, and to study the effects of dwell-fatigue and sustained loads on the crack growth behaviour at high temperatures.

\section{Author's contribution}

I performed parts of the mechanical testing, instrumentation, and have been the main contributor regarding the microstructure investigation, evaluation, and responsible for the manuscript writing. 


\section{Papers}

The articles associated with this thesis have been removed for copyright reasons. For more details about these see:

http://urn.kb.se/resolve?urn=urn:nbn:se:liu:diva-123306 